\title{
Using incentives to encourage AIDS programs and policies in the workplace: A study of feasibility and impact in Thailand
}

\author{
Simon Baker \\ Population Council \\ Srisuman Sartsara \\ Population Council \\ Patchara Rumakom \\ Population Council \\ Philip Guest \\ Population Council \\ Katie D. Schenk \\ Population Council
}

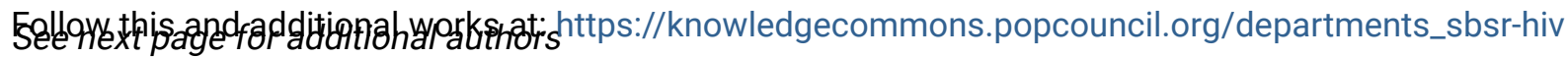

Part of the Demography, Population, and Ecology Commons, Health Economics Commons, Health Policy Commons, Immune System Diseases Commons, International Public Health Commons, Medicine and Health Commons, Public Health Education and Promotion Commons, Social Policy Commons, and the Virus Diseases Commons How does access to this work benefit you? Let us know!

\section{Recommended Citation}

Baker, Simon, Srisuman Sartsara, Patchara Rumakom, Philip Guest, Katie D. Schenk, Anthony Pramualratana, Suparat Suksakulwat, Surachai Panakitsuwan, and Sikarat Moonmeung. 2004. "Using incentives to encourage AIDS programs and policies in the workplace: A study of feasibility and impact in Thailand," Horizons Final Report. Washington, DC: Population Council. 


\section{Authors}

Simon Baker, Srisuman Sartsara, Patchara Rumakom, Philip Guest, Katie D. Schenk, Anthony

Pramualratana, Suparat Suksakulwat, Surachai Panakitsuwan, and Sikarat Moonmeung 


\section{Using Incentives to Encourage AIDS Programs and Policies in the Workplace}

\section{A study of feasibility and impact in Thailand}

\section{Hprizons N}
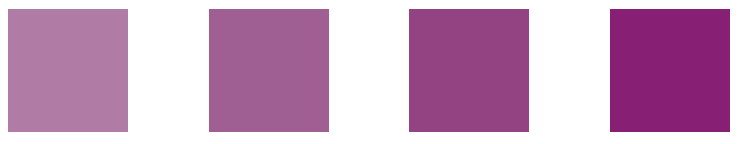

Horizons Program

Thailand Business Coalition on AIDS 


\section{Using I ncentives to Encourage AI DS Programs and Policies in the Workplace:}

\section{A study of feasibility and impact in Thailand}

Simon Baker ${ }^{1}$, Srisuman Sartsara ${ }^{1}$, Patchara Rumakom ${ }^{1}$, Philip Guest ${ }^{1}$, Katie Schenk ${ }^{1}$, Anthony Pramualratana ${ }^{2}$, Suparat Suksakulwat ${ }^{2}$, Surachai Panakitsuwan ${ }^{2}$, and Sikarat Moonmeung ${ }^{2}$

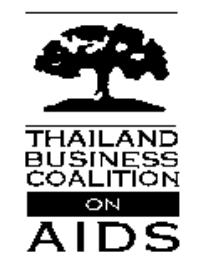

\section{${ }^{\mathrm{H}}$ rizons}

${ }^{1}$ Horizons/Population Council

${ }^{2}$ Thailand Business Coalition on AIDS 
USAID ind

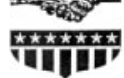
under the terms of HRN-A-00-97-00012-00. The opinions expressed herein are tho

Published in February 2004.

The Population Council is an international, nonprofit, nongovernmental (2) Population Council institution that seeks to improve the well-being and reproductive health of current and future generations around the world and to help achieve a humane, equitable, and sustainable balance between people and resources. The Council conducts biomedical, social science, and public health research and helps build research capacities in developing countries. Established in 1952, the Council is governed by an international board of trustees. Its New York headquarters supports a global network of regional and country offices.

Copyright () 2004 The Population Council Inc.

This document may be reproduced in whole or in part without permission of the Population Council provided full source citation is given and the reproduction is not for commercial purposes.

Suggested citation: Baker, Simon, Anthony Pramualratana, Srisuman Sartsara, Patchara Rumakom, Philip Guest, Katie Schenk, Suparat Suksakulwat, Surachai Panakitsuwan, and Sikarat Moonmeung. 2004. Using Incentives to Encourage AIDS Programs and Policies in the Workplace: A study of feasibility and impact in Thailand. Horizons Final Report. Washington, D.C.: Population Council. 


\section{Acknowledgments}

Several years of planning and advocacy have gone into the development of this project. The idea of the project came in 1995 when personnel from American International Assurance (AIA) (Thailand) approached the Thailand Business Coalition on AIDS (TBCA) to discuss an innovative program concept that matched financial incentives to a group-life insurance program on HIV/AIDS.

A financial supporter was sought and found for this program, but only later were we to find out that this donor was reducing activities in Thailand and could only support 50 percent of the total project. Continued negotiations led to AIA (Thailand) agreeing to fund the program on a cost-shared basis. A few months later, we were informed that the supporter could not provide any funds at all. We were left with a partially supported program. Nevertheless, we believed that this was a special program, never before attempted, and we felt committed to carrying it out. During this time I came across a book written by a leading nongovernmental organization fundraiser. An idea in the book inspired me to seek further funding. The author stated that she felt very strongly about a proposal's contribution to society, so she made 40 photocopies of the proposal, developed a list of potential supporters, and approached each one of them individually to seek their support.

I was struck by this simple yet sound strategy. I made ten photocopies of our proposal, developed a short list of potential supporters, and set aside seven days to approach them individually. I was surprised to find that within three days I had both a financial and technical supporter, who saw the innovativeness of the project and that these objectives matched the goals of Horizons. Dr. Chris Elias of the Population Council, now the president of PATH, was this person, and I would like to thank him for sharing our vision of the potential for expanding our idea nationally and internationally.

Special thanks must be given to Khun Suthi Rajitrangson, AIA senior vice president, who saw the long-term benefits of the project for the insurance industry in general and for Thai society at large. From the very beginning of the project, Khun Suthi spent many hours developing the project's conceptual design, company evaluation criteria, and questionnaires. Khun Suthi also made a presentation at the $5^{\text {th }}$ ICAAP in Kuala Lumpur on Business Commitment to Action and a presentation at the award ceremony of the Global Business Council on AIDS in 1998 in London. Our debt of gratitude to him is immeasurable.

Thanks also must go to Galayanee Chaturaphit, corporate communication officer of AIA for her continued and sincere support throughout the project. Finally, this project would not have been possible without the key contribution of Khun Veerasak, director of the Group Insurance Division at AIA. Khun Veerasak assisted in the continued task of providing us with a regular and updated list of AIA clients and agents throughout the country and was one of our main contacts throughout the project. We also wish to acknowledge Dr. Peter Crelinsten, AIA medical officer, as well as our former executive director, Dr. Supanya Lamsam, who together came up with the idea of developing a financial incentive scheme that rewards companies that implement HIV/AIDS prevention and nondiscrimination programs.

Editing and layout were conducted by Margaret Dadian, Alison Clarke, and Sherry Hutchinson of Horizons/Population Council, Washington, DC. Ellen Weiss and Andy Fisher undertook the technical review. Thanks to Gunnar Walzholz of the International Labour Organisation, and Julie Pulerwitz of Horizons/PATH, Washington DC, for their helpful comments.

Dr. Anthony Pramualratana, Executive Director, Thailand Business Coalition on AIDS 



\section{Table of Contents}

\section{Abbreviations}

Executive Summary

Introduction $\quad 5$

Background $\quad 5$

Aims 6

$\begin{array}{ll}\text { Conceptual framework } & 6\end{array}$

$\begin{array}{ll}\text { Study site and population } & 7\end{array}$

Methods 9

$\begin{array}{lr}\text { Intervention } & 9\end{array}$

$\begin{array}{ll}\text { Data collection } & 11\end{array}$

Results $\quad 16$

$\begin{array}{ll}\text { Company recruitment and participation } & 16\end{array}$

$\begin{array}{ll}\text { Workplace impact } & 28\end{array}$

Employees $\quad 38$

$\begin{array}{ll}\text { Cost-benefit analysis } & 44\end{array}$

Lessons Learned $\quad 46$

Next Steps $\quad 50$

$\begin{array}{ll}\text { References } & 51\end{array}$

Further reading $\quad 52$ 


\section{Abbreviations}

$\begin{array}{ll}\text { AIA } & \text { American International Assurance, Thailand } \\ \text { AIDS } & \text { Acquired Immune Deficiency Syndrome } \\ \text { ASO } & \text { AIDS-response Standard Organization } \\ \text { HIV } & \text { Human Immunodeficiency Virus } \\ \text { ILO } & \text { International Labour Organisation } \\ \text { KAB } & \text { Knowledge, attitudes, and behavior } \\ \text { NGO } & \text { Nongovernmental organization } \\ \text { PLHA } & \text { People living with HIV/AIDS } \\ \text { SAQ } & \text { Self-administered questionnaire } \\ \text { SW } & \text { Sex worker } \\ \text { TBCA } & \text { Thailand Business Coalition on AIDS } \\ \text { UNAIDS } & \text { Joint United Nations Programme on HIV/AIDS } \\ \text { WHO } & \text { World Health Organization }\end{array}$




\section{Executive Summary}

Employers and company managers have an important role to play in creating work environments free from AIDS-related stigma and discrimination. Implementing HIV/AIDS policies in the workplace can curb such unfair employment practices as compulsory HIV testing and can help meet the needs of people living with HIV/AIDS for confidentiality and assistance.

A recently completed Horizons study in Thailand examined the question of how to encourage the private sector to become actively involved in developing and improving workplace HIV/AIDS programs. Researchers investigated the role of incentives in encouraging companies to adopt workplace policies and programs that address stigma and discrimination and respond to the needs of workers for information and services. The research was conducted in partnership with American International Assurance (AIA), the Thailand Business Coalition on AIDS (TBCA), and AusAID, the overseas development agency of the Australian government.

The investigators explored the process and outcomes of offering incentives to encourage companies to improve their workplace HIV/AIDS policies and programs. They hypothesized that these incentives would motivate companies to introduce or improve their policies and activities, which in turn would result in improvements in employees' knowledge and behaviors.

\section{Intervention}

The initiative, known as the AIDS-response Standard Organization (ASO), was launched at a press conference that publicized the availability of incentives to encourage companies to implement HIV/AIDS workplace programs and policies. TBCA staff built relationships with company managers, in order to explain and promote the advantages of joining the initiative.

Companies agreeing to implement at least the minimum three required anti-discriminatory HIV/AIDS workplace policies received a reduction of 5 to 10 percent off their group life insurance premiums from AIA, Thailand's largest insurance provider, if they were AIA clients. As the initiative evolved, TBCA introduced the additional incentive of a certificate jointly endorsed by the Ministry of Public Health and the Ministry of Labour and Social Welfare, which was awarded at a high-profile public ceremony.

For each company agreeing to participate, TBCA offered assistance to enhance their activities, including providing educational leaflets, videos, and a mobile exhibition, as well as condoms, peer education training, counseling and referrals to support groups for HIV-positive employees, and assistance with writing company HIV/AIDS policies. 


\section{Hgrizons}

\section{Study Design and Data Collection Methods}

The study was conducted among companies in Bangkok, Chiang Mai, and neighboring provinces between May 2000 and April 2002. The researchers used a checklist to document the characteristics of the 857 companies that were invited to join the initiative, and conducted interviews with managers of 99 of the 125 companies that agreed to participate in ASO and 144 that declined to participate. Managers and approximately 9,000 employees from the 125 participating companies twice completed self-administered questionnaires, first when they joined the initiative and then again 18 months later. Data from the managers' questionnaires were used to determine a pre- and post-intervention accreditation score for each company.

\section{Key Findings}

\section{Managers were more motivated by a sense of social responsibility to improve their policies and programs than by the incentives offered for participation in the initiative.}

The most important reason cited by company managers for joining ASO and subsequently implementing HIV/AIDS policies in the workplace was an altruistic one: the opportunity to act in the best interests of their employees. Nearly 60 percent of the 125 company managers choosing to join ASO decided to participate because they felt a sense of responsibility to their workers and the wider community to do something about HIV/AIDS.

"The incentive... to be involved in the fight against AIDS is not simply about money or certificates, but about us giving our workers greater knowledge and providing them with additional training."

Manager, ASO participating company

Managers reported that other motivations to join the initiative were that ASO would allow them to find out how their HIV/AIDS policies and programs compare to those of other companies, and to better understand the disease and how employees may be at risk due to their behavior.

Only 11 percent of managers who participated said that they had joined ASO for its financial benefits, while the rest - particularly smaller companies with fewer resources-did not perceive the premium reduction as being enough to justify the additional costs of introducing the policies and activities. With life insurance coverage costing employers an average premium of $250 \mathrm{baht}$ (US $\$ 5.85$ ) per employee, the maximum reduction available was 25 baht (US \$0.60) per employee.

"To be honest, it is only a small amount. Seeing that we would have to invest time, it would be time consuming and complicated."

Manager, nonparticipating company

Neither did company managers value the certificate nor attach much importance to receiving it at a public ceremony. They indicated that the certificate would have had greater value if it had been endorsed by a well-known international organization or the Thai royal family; or if the initiative 
itself had been better known in the first place, thereby making achievement of the certificate a significant accomplishment.

"Our hotel has so many [certificates] that I do not know where to put them. I am not interested in the certificate unless it came from someone really important."

Manager, ASO participating company

Researchers also discovered that some managers declined to join because the sign-up process appeared very complicated or because they suspected the incentive scheme was an AIA marketing ploy, since only AIA clients were entitled to the insurance discount.

\section{Managers with closer or preexisting connections to the initiative, such as physical location, staff contacts, or company commitment to HIV, were more likely to participate.}

Overall participation in the initiative was 1 percent of the 857 companies originally invited. Participating companies included factories, hotels, and commercial and professional firms, as well as companies of diverse size and ownership characteristics. Company characteristics associated with higher levels of participation in the initiative included a history of previous involvement in HIV/AIDS activities and the manager's personal commitment to the issue. The most successful method of recruiting companies was approaching companies and individuals already known to TBCA. Locally owned and headquartered companies had significantly higher participation levels than those in which the locus of decision-making was physically more distant. Larger companies, to whom the fixed costs of the required policy changes represent a proportionately smaller burden, might have been more likely to sign up for the initiative.

\section{Most participating companies improved their HIV/AIDS policies and programs.}

ASO had a marked impact on the workplaces of participating companies, with 82 percent of participants improving their accreditation score between the two rounds. Overall, the mean total accreditation score increased from 37 to 51 points out of a maximum of $100(\mathrm{p}<.001)$.

\section{Broad policy improvements were not associated with specific changes at the employee level.}

The self-administered questionnaires completed by employees indicated very limited changes in the knowledge and behavior of individuals. This is not surprising, since an intervention designed for impact on individual risk behaviors must go beyond the policy level to directly and consistently reach employees over a significant time period. 


\section{Hgrizons}

\section{Among participating companies, financial incentives were associated with greater policy improvements.}

Although the financial incentive was perceived to be insufficient to motivate many companies to join ASO, it likely played a positive role once companies had already signed up. About a third of 125 companies that joined ASO held AIA group life insurance policies and were eligible for premium reductions. These AIA member companies showed greater improvements in their policies and spent more to improve their programs than did the non-AIA member companies that joined ASO and were thus ineligible for financial benefits. Financial rewards can clearly have an impact on company polices and programs, but their influence in this study was limited to policy implementation and not company recruitment.

\section{Conclusions and Next Steps}

The study found that the ASO initiative mobilized a moderate proportion of different types of companies to develop and improve HIV/AIDS workplace policies and programs. Although many managers were not motivated by the incentives to sign up, a significant proportion had an untapped sense of responsibility to act in the best interests of their employees by joining ASO. The data also reveal that companies that were eligible for the insurance discount made the greatest improvements. Thus a financial incentive combined with efforts to tap into managers' willingness to respond to the epidemic can be important motivators for certain companies to improve their workplace environment.

Despite improvements at the workplace, there was no impact on employees' HIV-related knowledge and behavior. One reason may be that the focus of ASO was on nondiscriminatory policies, which help to safeguard workers' rights but likely do little to foster sexual risk-reduction behaviors. Also, while TBCA offered companies a menu of materials and services to improve workplace HIV/AIDS programs, the inputs requested may not have been sufficiently intense to result in improvements robust enough to make a difference in workers' knowledge and behaviors. Therefore, in future endeavors, more attention needs to be paid not only to participation but also to the program content of HIV/AIDS workplace activities.

Building on the findings of this study, a modified version of the initiative will be scaled up to 25 provinces in Thailand, beginning in late 2003. TBCA has received funding from the Global Fund to recruit 2,500 workplaces to participate in the new program, in cooperation with the Ministry of Public Health, the Ministry of Labour and Social Welfare, business groups, AIA, and local nongovernmental organizations. 
Workplace AIDS Program in Thailand

\section{Introduction}

\section{Background}

\section{HIV/AIDS in Thailand}

Thailand has received international attention as one of the few developing countries to begin to see the impact of efforts to prevent the spread of HIV/AIDS at a national level. Since the onset of a national AIDS education and prevention campaign in 1990-91, evidence has documented a reduction in the number of visitors to sex workers, an increase in condom usage, a dramatic decline in STI prevalence, and substantial reductions in the number of new HIV infections. Data indicate that the number of new HIV cases in Thailand peaked in the early 1990s, and that an estimated 200,000 new infections have been averted since 1993 (World Bank 2000). Despite the reduction in new infections, an estimated 700,000 people of Thailand's total population of 61 million are currently living with HIV/AIDS. Thailand will continue to face high levels of demand for medical services as the epidemic matures, and households will continue to face poverty as people living with HIV progress to more advanced stages of disease.

\section{HIV/AIDS programs in the workplace}

The workplace setting is considered an effective environment for delivering HIV/AIDS programs to a wide range of people who might not otherwise have access to HIV/AIDS prevention education, and raise their awareness of care and support services. Business can play a vital role in HIV/AIDS prevention, care, and support efforts, by distributing condoms, providing voluntary counseling and testing, and expanding access to care and treatment. Mobilizing corporate resources in resourceconstrained regions may prevent further economic and social damage, which after all is in the best interests of businesses and individuals alike.

Private enterprises responding to the increasing impact of HIV/AIDS on the economy have initiated workplace programs and policies (for example, see International Labour Organization 2003a; World Economic Forum Undated b). Firms have responded in various ways to the dual challenges of losing skilled and experienced employees to illness, while simultaneously facing increased health insurance and training costs (UNAIDS 2002; UNAIDS 1998). These workplace programs and policies have often been introduced by international bodies or so-called "champion" enterprises: large companies or umbrella organizations in high HIV prevalence areas that have realized the importance of creating "HIV/AIDS-friendly" workplace environments (e.g., Durban Chamber of Commerce, Undated; International Labour Organization 2003b; International Labour Organization 2003c; International Labour Organisation 2003d; World Economic Forum Undated a). Trade unions and groups of people living with HIV/AIDS (PLHA) have also been responsible for the creation of workplace programs (for example Joint United Nations Programme on HIV/AIDS 2002; Southern African Clothing and Textile Workers' Union 2002; GIPA Undated). However, despite the growth in HIV/AIDS workplace programs, success to date has been limited: 


\section{Hgrizons}

the examples set by the "champion" companies have not led to the widespread adoption of similar schemes across regions or industries. Many enterprises remain unmotivated or unaware of how to be actively involved in the fight against HIV/AIDS, in part because no mechanism exists to educate managers about potential benefits and show them how to introduce workplace programs and policies.

Thailand was selected as an appropriate country in which to pilot this workplace initiative due to the existence of previous multisectoral HIV/AIDS initiatives by governmental and nongovernmental organizations (NGOs). In particular, the Thailand Business Coalition on AIDS (TBCA) had been working with businesses in Thailand to promoting workplace HIV/AIDS education and prevention programs for employees since its inception in 1993. Although TBCA had achieved success in encouraging businesses to manage HIV and AIDS in the workplace, most companies still had difficulty seeing the financial benefit of such schemes, and thus the opportunity to investigate incentives was particularly timely.

\section{Aims}

This research study aimed to explore company managers' decision-making process in developing workplace HIV/AIDS programs, and the extent to which incentives could be used to influence this process.

This study addresses the following research questions:

Feasibility and impact of the initiative

- Can a scheme offering companies a reduction in group-life-insurance rates result in improvements in workplace HIV/AIDS programs?

- Do improvements in workplace HIV/AIDS programs, as measured through the accreditation process, result in improvement in the knowledge, attitudes, and behavior (KAB) of company employees?

Managerial decision-making

- How do managers perceive the costs and benefits of participation in the scheme?

- Why do some companies agree to participate and others refuse to participate in the scheme?

\section{Conceptual Framework}

The investigators explored the process and outcomes of offering incentives to encourage companies to improve their workplace HIV/AIDS policies and programs. They hypothesized that these incentives would motivate companies to introduce or improve their policies and activities, which in turn would eventually result in improvements in employees' knowledge and behaviors, as shown in Figure 1. 
Figure 1 Hypothesized impact of study

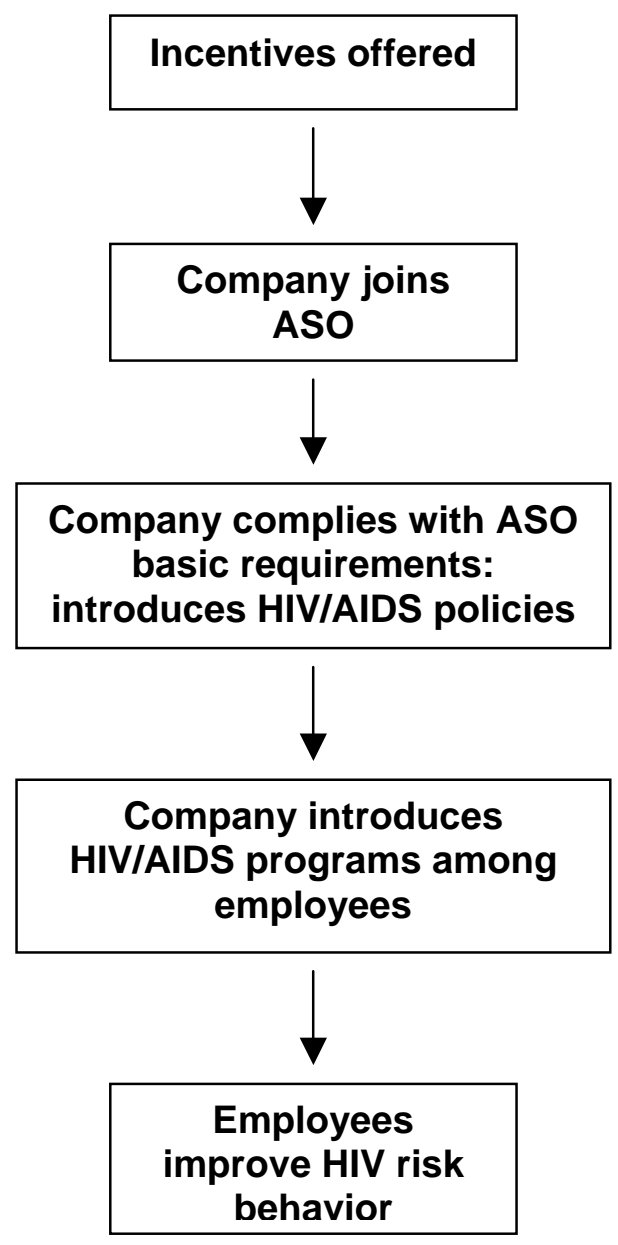

\section{Study Site and Population}

Companies participating in this study were located in Bangkok and nearby provinces ${ }^{1}$ and in Chiang Mai and its neighboring province of Lamphun (Figure 2). Bangkok and its surrounding region were selected since most of Thailand's companies are located in this area, and TBCA already had a network there. Chiang Mai, the largest city in northern Thailand, was chosen because it is the area most affected by the Thai AIDS epidemic, and also has a relatively large and varied employment base, which includes AIA members, and a high percentage of local ownership. Lamphun has several industrial estates where a number of companies expressed interest in participating in ASO.

\footnotetext{
${ }^{1}$ Samutprakarn, Patumthani, Ayuddhaya, Chacheongsao, Nonthaburi, Prachinburi, and Samutsakorn
} 
Hgrizons

Figure 2 Map of Thailand, showing study areas

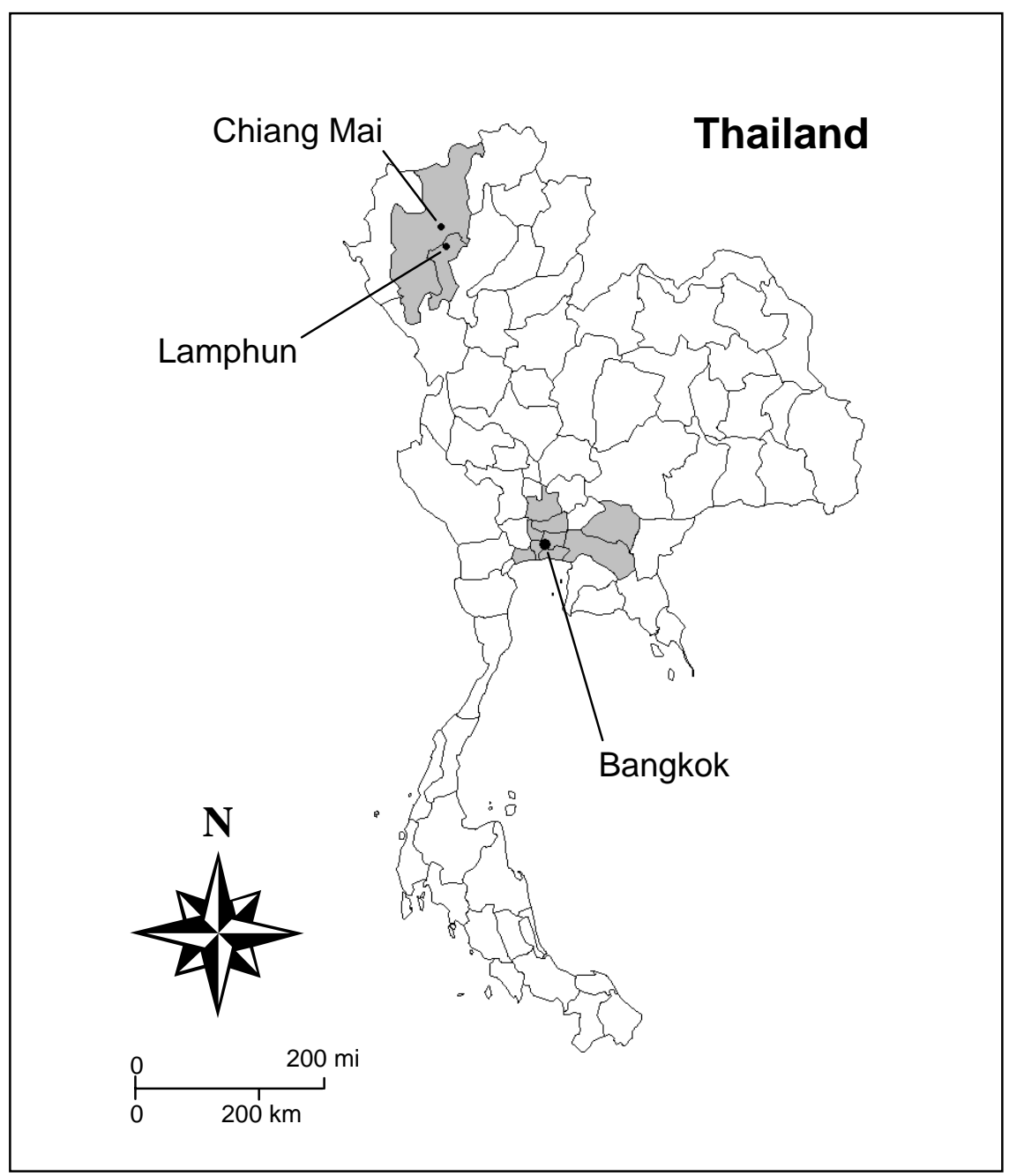




\section{Methods}

\section{Intervention}

Study partners developed an insurance scheme called the AIDS-response Standard Organization (ASO) that awarded graduated reductions in group-life insurance rates to companies that demonstrated improvements in their HIV/AIDS workplace policies and activities.

Companies agreeing to implement at least three HIV/AIDS workplace policies would receive a reduction of 5 to 10 percent off their group life insurance premiums from AIA, Thailand's largest insurance provider, if they were AIA clients. Full details of the qualification criteria are shown in the sidebar below. These criteria and the overall scoring system were developed following two pilot projects undertaken by TBCA and Horizons during 1998 and 1999, and subsequent discussions with AIA senior representatives.

As the initiative evolved, TBCA introduced the additional incentive of a certificate awarded by the directors general of the Department of Disease Control (Ministry of Public Health) and of the Department of Labour Protection and Welfare (Ministry of Labour and Social Welfare) at a highprofile public ceremony.

For all companies agreeing to participate, TBCA offered assistance to enhance their activities, including providing educational leaflets, videos, and a mobile exhibition, as well as condoms, peer education training, counseling and referrals to support groups for HIV-positive employees, and assistance with writing company HIV/AIDS policies.

\section{Insurance Premium Reduction Qualification Criteria}

Companies qualified for the minimum 5 percent reduction if they signed onto a declaration declaring that they met the three key policy requirements:

- Did not test job applicants for HIV/AIDS.

- Did not test employees for HIV/AIDS.

- Continued to employ workers known to be HIV-positive.

Further reductions up to a maximum 10 percent reduction were awarded to companies that demonstrated a comprehensive workplace HIV/AIDS program for employees by adhering to the three basic policies and additionally:

- Informing their employees of the company's HIV/AIDS policies.

- Maintaining confidentiality of the HIV status of employees.

- Providing assistance to HIV-positive employees.

- Making training and information on HIV/AIDS available to employees, including promotion and distribution of condoms.

- Being involved with HIV/AIDS activities in the wider community. 


\section{Hgrizons}

\section{Partners}

TBCA implemented the intervention, monitored standards and compliance, and managed data collection and analysis. As an NGO receiving donor funding, and at the same time a business association seeking private sector membership, TBCA staff had multiple potentially overlapping or conflicting roles and responsibilities. Thus the close involvement of other partners was maintained to ensure data quality.

Horizons was responsible for the operations research component of the study and supervised the data collection to ensure data quality and accurate analysis and reporting of results.

AIA, Thailand's largest insurance provider, was responsible for administering the insurance premium reductions among member companies.

AusAID, the overseas aid program of the Australian Government, provided funding for the press conference and for questionnaire development.

\section{Launch}

The project was launched in June 2000 at a high-profile press conference attended by representatives of UNAIDS, WHO, and the Thai government (Ministry of Public Health, Ministry of Social Welfare), as well as the general public. Representatives of local businesses were invited from a list of company contacts compiled by AIA and TBCA, and from commercial associations and personal networks of the TBCA board members. Television and print media representatives were also present. Materials distributed at the press conference included information on the intervention and the partners in Thai and English.

\section{Recruitment}

The press conference generated coverage in both the English and Thai language media. TBCA followed up on the initial publicity by contacting the company representatives who had attended the launch and representatives of other invited companies.

TBCA staff provided company representatives with further details of ASO sent by mail or fax. This information was followed up with telephone calls to the personnel manager, with the aim of setting up an appointment to discuss and market ASO. At these meetings, the TBCA team member began to establish a one-on-one relationship with the company representative, and provided a package detailing the requirements and benefits to the company of joining ASO and being involved in the research activities.

TBCA aimed to enroll 150 companies, most of which were expected to be AIA clients. However, recruitment did not proceed according to plan. Two surprising findings emerged, in light of which recruitment policies were changed: 
First, it became apparent that recruitment of AIA member companies was lower than expected. By the close of recruitment in May 2001, only 125 companies had enrolled in ASO, of which 42 received AIA insurance. This finding suggested that the value of the insurance premium reduction that was being offered was an insufficient incentive for companies to join ASO.

Second, many companies without AIA life insurance were still interested in joining the scheme, even though they were unable to take advantage of the premium reductions on offer without changing insurance provider. Furthermore, it was clear that the costs and complexities of changing insurance providers outweighed any potential advantage of reduced premiums.

Study investigators changed the recruitment criteria and incentive scheme to recognize both of these developments. They developed a certification scheme to visibly recognize and honor all companies committing to participation in the project. Certificates were signed and presented by a high-ranking representative of the Ministry of Public Health and the Ministry of Labour and Social Welfare at a public awards ceremony, designed to publicly honor all participating companies for their interest in the health and welfare of their workers, regardless of whether they were AIA clients.

Thus, the final intervention design upon which results are reported in this report includes both types of incentives offered to companies: insurance premium reductions and publicly awarded certificates.

\section{Data Collection}

\section{Data sources}

This study used the data sources detailed in Table 1. Data collection began in May 2000 and continued until April 2002².

\section{Data entry and analysis}

Data analysis was conducted using SPSS version 10.0. Unless otherwise stated, the statistical tests reported were Pearson $\mathrm{chi}^{2}$. An asterisk $(*)$ indicates results considered significant at the 0.05 level or below, and a double asterisk (**) indicates results considered significant at the 0.01 level or below. Throughout this report, note that percentages may not total 100 percent due to rounding error.

\footnotetext{
${ }^{2}$ All data collection instruments are available upon request from horizons@pcdc.org
} 
Table 1 Data collection methods and denominators

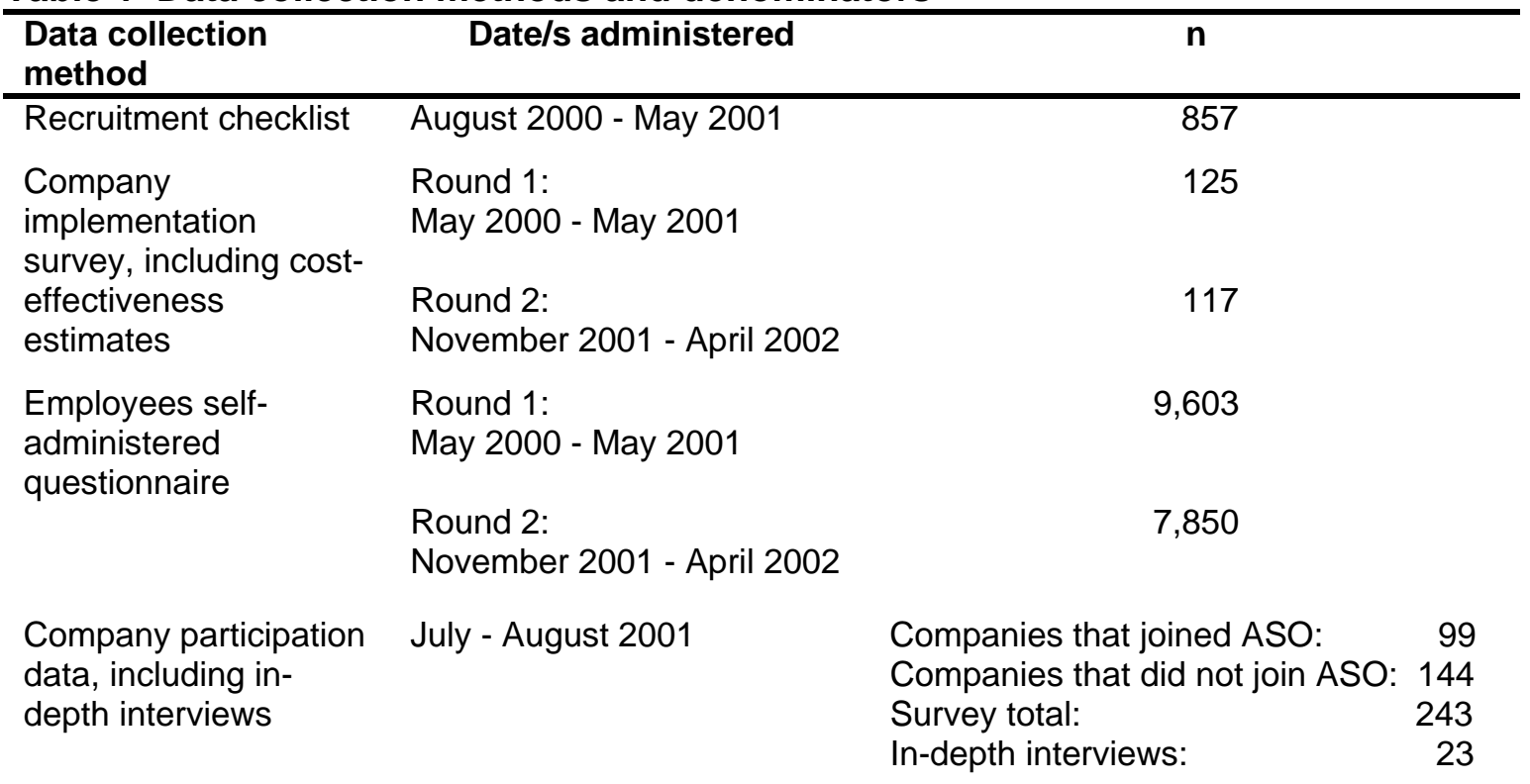

\section{Recruitment checklist}

Between August 2000 and May 2001, 857 companies (706 in Bangkok and its surrounding provinces and 151 in Chiang Mai and its neighboring province Lamphun $^{3}$ ) were invited to join ASO. TBCA recorded company characteristics using a recruitment checklist, including size and type of company, number of employees insured, type of insurance, and reasons for joining or not joining the ASO project.

\section{Company implementation survey}

For each company that agreed to join the scheme, TBCA carried out a structured survey with a personnel manager or other high-level company official, exploring management decisions in relation to the project and the extent to which the required policies had been implemented. The questionnaire, which took an average of about 45 minutes to complete, was administered twice: once at the time of recruitment to ASO, and once in the year following the introduction of the ASO policies. Accreditation scores were assigned to indicate company performance in the following five fields:

\footnotetext{
${ }^{3}$ Unless stated, Bangkok refers to the city and its surrounding provinces, and Chiang Mai refers to both Chiang Mai and Lamphun.
} 
- Policy announcement.

- Confidentiality policy.

- Assistance to HIV-positive employees.

- HIV prevention activities at the workplace.

- Social contribution.

The pre-post intervention design of this study component enabled researchers to observe changes in company policies and programs over the period of the intervention.

\section{Cost-effectiveness estimates}

The company questionnaire included a form to record monetary costs and benefits of the scheme, including the costs of personnel time and effort, the benefits of savings from the premium rate reduction, productivity gains, and health care savings from improved employee health.

\section{Employee self-administered questionnaire}

A self-administered questionnaire (SAQ) was distributed to at least 100 employees at each company, or to 100 percent of the workforce for small companies. Total sample size was 9,603 at Round 1 and 7,850 at Round 2. As with the company manager questionnaires, the SAQs were administered on two occasions - once before and once after the introduction of the interventionwhich allowed examination of pre-post changes in employee knowledge, attitudes, and behavior. Sample size calculations indicated that these large numbers of employees were required to detect small changes with sufficient power from the initial levels assumed.

The time required for individual employees to fill out the SAQ was approximately 15 minutes. Because of restrictions imposed by company management, in only a few cases was TBCA able to directly distribute the SAQ to the employees. In most cases, TBCA made arrangements with the manager to distribute the SAQ to the employees. These arrangements included distributing the questionnaire to every section of the workplace in a proportional way so as to reflect the company's gender balance. The companies took between two and four weeks for all employees to complete the questionnaire.

\section{Company participation data}

Realizing the difficulties of recruiting companies, and in particular AIA clients, to join ASO, the researchers and TBCA decided to conduct a qualitative exploration of the reasons why some companies agreed to join while others refused to participate in the program. As a result, between July and August 2001 a questionnaire was mailed to all 857 companies that had been originally invited to join ASO. The questionnaire covered: 


\section{Hgrizons}

- Managers' attitudes about HIV/AIDS workplace activities.

- How they received information about the project.

- Knowledge about ASO.

- Companies' HIV/AIDS policies.

- Reaction to the financial incentives and the certificate.

- The decision-making process in the company.

- Companies' HIV/AIDS activities.

Qualitative data quoted below are labeled according to the size of the company ${ }^{4}$ and whether the informant was a manager of a company that did or did not join ASO.

\section{Response rates}

Researchers mailed the qualitative questionnaires to all of the 857 companies that had originally been invited to join the project. All companies that had subsequently joined ASO were followed up with a series of telephone calls. Companies that had not joined were followed up with less intensity: only 30 percent, systematically sampled by the date that they declined to join, were followed up with telephone calls.

Response rates (Table 2) were 79 percent among companies that joined and 20 percent of those that had not joined. Caution should be taken in the interpretation of the views of companies that had not joined ASO, given the low response rate.

Table 2 Responses to mailed questionnaires

\begin{tabular}{lccc}
\hline $\begin{array}{l}\text { Type of } \\
\text { company }\end{array}$ & $\begin{array}{c}\text { Questionnaires } \\
\text { sent }\end{array}$ & $\begin{array}{c}\text { Responses } \\
\text { received }\end{array}$ & $\begin{array}{c}\text { Response rate } \\
\%\end{array}$ \\
\hline Joined ASO & 125 & 99 & 79 \\
Did not join ASO & 732 & 144 & 20 \\
Total & 857 & 243 & 28
\end{tabular}

In addition, researchers conducted 23 in-depth interviews with company decision makers in Bangkok to explore their reasons for participation or nonparticipation. A stratified random sampling method was used to ensure that AIA members and nonmembers, and companies of varying size were represented. Interviews examined managers' perceptions of the costs and benefits of ASO and their personal attitudes toward HIV/AIDS.

\footnotetext{
${ }^{4}$ Cut-off point between large and small companies is defined as 200 employees.
} 


\section{Study limitations}

The use of probability sampling techniques was not feasible in this study. The companies selected for inclusion in the survey samples were based on a list compiled mainly through the personal contacts of TBCA staff (see section below on Recruitment strategies). The inability to ensure that employees were randomly sampled limits the generalizations that can be made from the data. 


\section{Hgrizons}

\section{Results}

In this section, we present combined results from the different data collection tools explained above.

\section{Company Recruitment and Participation}

\section{Respondent profile}

By May 2001, when recruitment for the first round of data collection closed, 125 companies had joined ASO, including 75 from Bangkok and neighboring provinces and 50 from Chiang Mai and Lamphun. By round 2, the total number of participating companies declined to 117, due to a few companies dropping out of the project or going out of business.

Table 3 shows the descriptive characteristics of the companies signing up to the HIV/AIDS workplace policies. Over half of all companies joining ASO were factories. Other types of enterprises joining the scheme included hotels (particularly in Chiang Mai) and commercial and professional firms. Most companies joining ASO were not AIA clients and were therefore not entitled to a financial benefit. Companies in Chiang Mai were less likely to be AIA clients than those in Bangkok. The companies participating in Bangkok were generally larger than those in Chiang Mai.

\section{Recruitment strategies}

TBCA compiled its list of company contacts through various means, including personal and professional networks, directory listings, and publicizing the project at the meeting of the chamber of commerce.

Personal contacts were significantly the most successful contact method (Figure 3), although this group was also the smallest in number contacted. Through this method TBCA was able to directly meet the decision maker, explain the details of ASO, and obtain a rapid decision. With other, less personal strategies TBCA representatives had to work their way up the company structure, using a contact list that may have been out of date, hoping to find the appropriate individual with decisionmaking power to determine the company's participation.

The important point in deciding to join or not was reaching the executive. We had to have enough information for them to see the picture. We had to explain to them so that they could understand. We had to have enough information to see both the benefits and the disadvantages of the project. 
Table 3 Characteristics of participating companies

\begin{tabular}{|c|c|c|c|c|c|c|}
\hline \multirow[b]{2}{*}{ Characteristics } & \multicolumn{3}{|c|}{ Round 1} & \multicolumn{3}{|c|}{ Round 2} \\
\hline & $\begin{array}{c}\text { Bangkok } \\
\mathrm{n}=75 \\
\%\end{array}$ & $\begin{array}{c}\text { Chiang Mai } \\
n=50 \\
\%\end{array}$ & $\begin{array}{c}\text { Total } \\
n=125 \\
\%\end{array}$ & $\begin{array}{c}\text { Bangkok } \\
\mathrm{n}=69 \\
\%\end{array}$ & $\begin{array}{c}\text { Chiang Mai } \\
n=48 \\
\%\end{array}$ & $\begin{array}{c}\text { Total } \\
\mathrm{n}=117 \\
\%\end{array}$ \\
\hline \multicolumn{7}{|l|}{$\begin{array}{l}\text { Type of } \\
\text { business }\end{array}$} \\
\hline Factory & 64 & 38 & 54 & 64 & 35 & 52 \\
\hline Hotel & 25 & 36 & 30 & 25 & 38 & 30 \\
\hline $\begin{array}{l}\text { Commercial } \\
\text { services }\end{array}$ & 4 & 20 & 10 & 4 & 21 & 11 \\
\hline $\begin{array}{l}\text { Professional } \\
\text { firms }\end{array}$ & 7 & 6 & 6 & 7 & 6 & 7 \\
\hline \multicolumn{7}{|l|}{ AlA clients } \\
\hline No & 61 & 74 & 66 & 65 & 85 & 74 \\
\hline Yes & 39 & 26 & 34 & 35 & 15 & 27 \\
\hline \multicolumn{7}{|l|}{$\begin{array}{l}\text { Number of } \\
\text { employees }\end{array}$} \\
\hline Median & 472 & 153 & 325 & 485 & 147 & 310 \\
\hline Min & 24 & 32 & 24 & 26 & 33 & 26 \\
\hline Max & 8,500 & 2,677 & 8,500 & 9,000 & 1,960 & 9,000 \\
\hline
\end{tabular}

Figure 3 Participation by company contact method

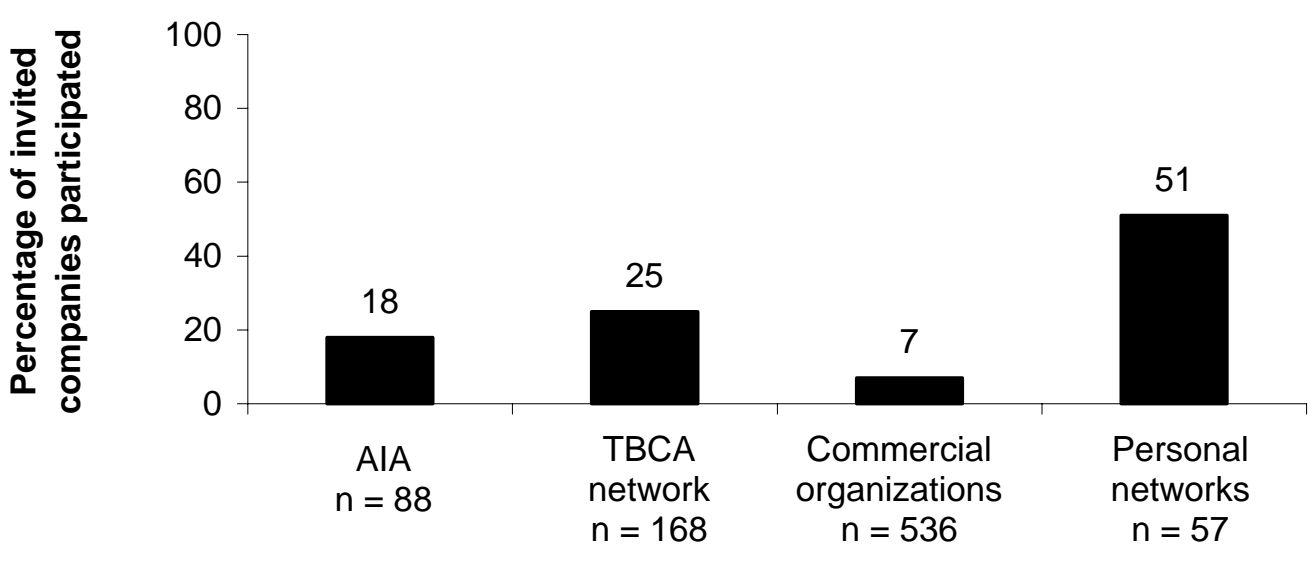

Contact method 


\section{Hgrizons}

According to in-depth interviews with company managers, the lengthy recruitment process discouraged some managers from participating. Interviewers also discovered a variety of misperceptions about the initiative. For example, some managers declined to participate because they incorrectly perceived the scheme to be a marketing strategy of the insurance provider AIA.

The fact that AIA is the sponsor of the project run by TBCA creates an image that is too business oriented. If the project were run by the government or by the Insurance Association we wouldn't see it as an AIA project, but as a cooperative project. We would see it as a social issue, a social security issue, or a public health issue. Thus it would have a different image. The way it is now it seems that TBCA is AIA. This is my belief.

Manager, large nonparticipating company

Convincing companies to join the project proved time consuming. Numerous follow-up contacts were often necessary before company managers could be convinced to join the ASO project. Only 12 percent of companies joined after the first contact, with up to seven contacts necessary before some companies decided to participate, thus making the project more labor-intensive than expected (Figure 4). Many companies that did not join the project were also contacted numerous times before finally deciding not to participate in the project.

Figure 4 Companies agreeing to join ASO, by number of contacts

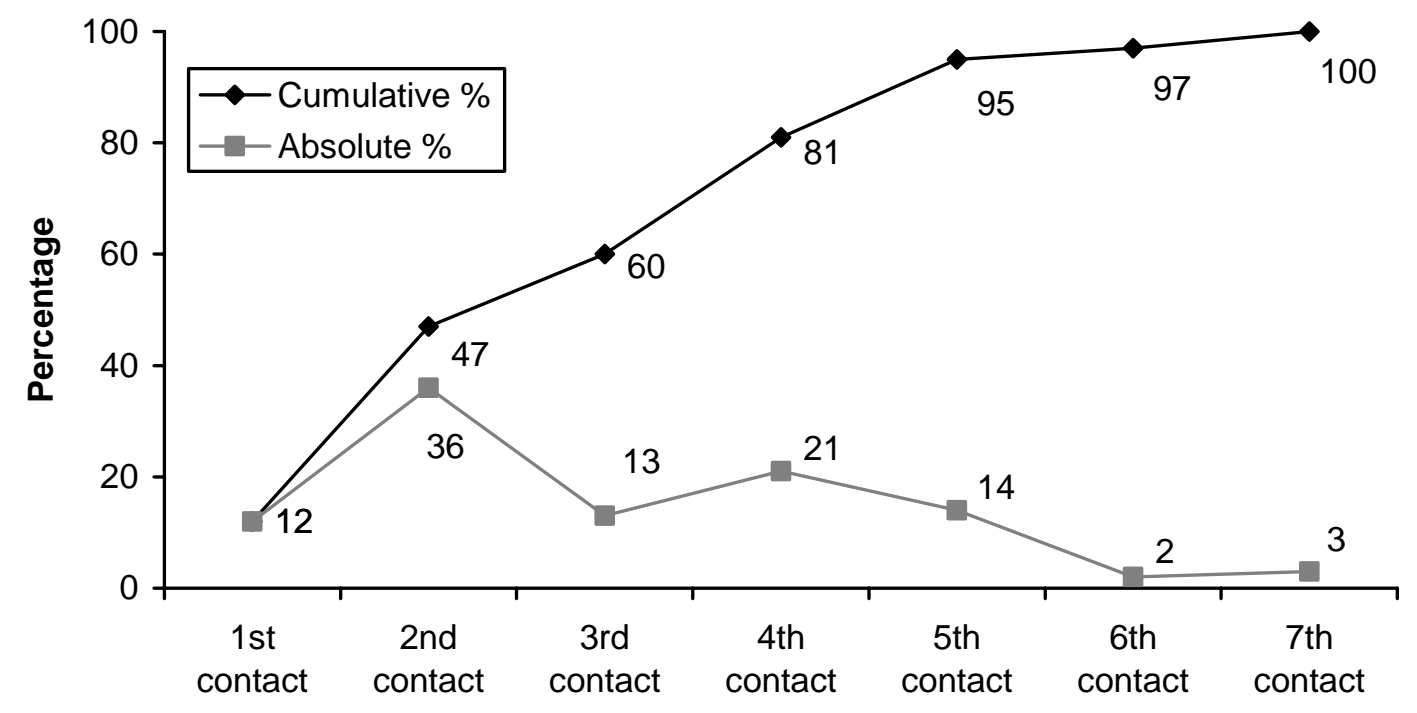

Note: This graph illustrates only the results of 121 companies that eventually decided to join the project. 


\section{Decision-making process}

\section{Reasons why companies joined ASO}

Managers of companies joining the scheme were asked to list their motivations for participation. The most commonly given reason for joining the ASO project was a sense of social responsibility to employees and to society as a whole (Figure 5): 57 percent of company managers joining ASO said that it was because they wanted to establish HIV/AIDS workplace activities to help their workers and members of their community.

The incentive for private enterprises to be involved in the fight against AIDS is not simply about money or certificates, but it is about us giving our workers greater knowledge and providing our workers with additional trainings at the workplace.

Manager, large ASO participating company

The second most popular motivation for joining, mentioned by 30 percent of companies recruited, was to know the results of the company and employee surveys and to find out how their policies and employee characteristics compared with other companies. This finding highlights the importance of a publicly recognized standard (e.g., through government endorsement or a national Code of Practice) to provide guidance on appropriate responses to HIV/AIDS in the workplace.

We joined ASO so to know what our standard was. We wanted to know what areas we needed to improve [in relation to HIV/AIDS]; we were more interested in that. ... we joined to see where our company was lacking, or what we had to do extra to help our employees who are at risk of contracting HIV/AIDS.

Manager, large ASO participating company

\section{Figure 5 Reasons why companies joined ASO}

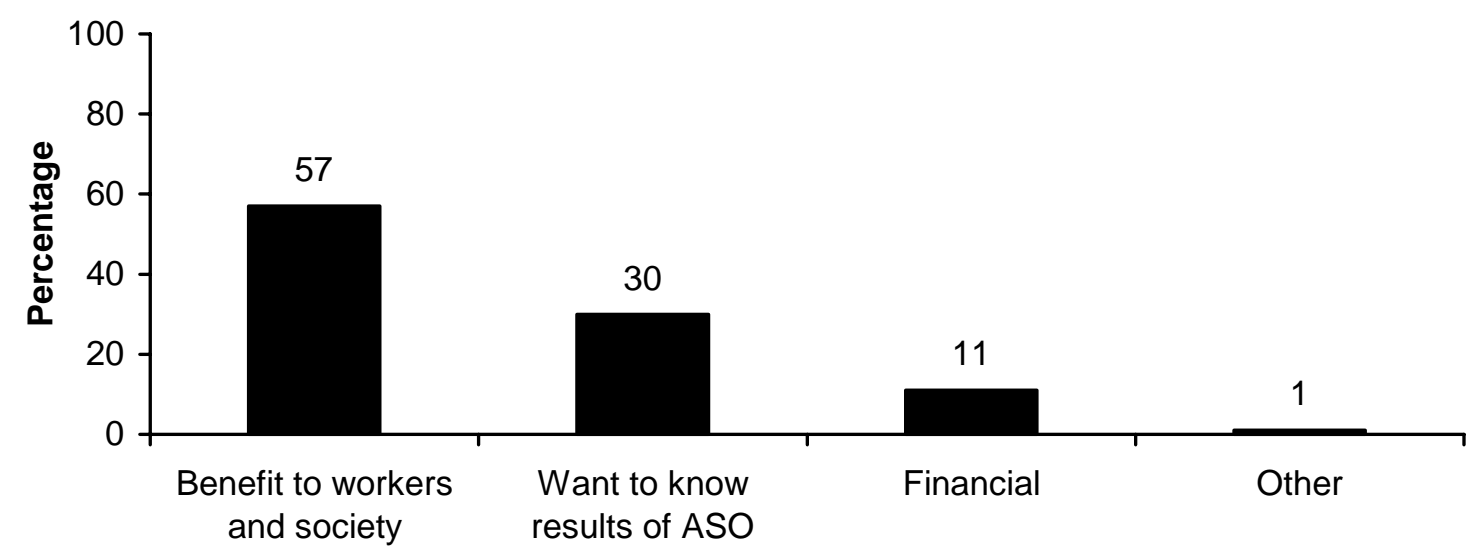

Note: $\mathrm{n}=96$ responses based on 125 companies recruited, multiple responses allowed. 


\section{Hgrizons}

Almost all managers of companies that joined (96 percent) agreed with the statement that knowing about employees' HIV knowledge and risk behavior would help them to plan prevention activities. Even among companies that did not join ASO, 79 percent of managers agreed with this statement and thought that such information would have been useful, although they had evidently declined to participate in the scheme for other reasons (see below).

The financial benefit of a reduction in the costs of group life insurance premiums was cited as a reason to join ASO by only 11 percent of company managers. Many of the managers who decided not to join indicated during their interviews that they perceived the financial rewards as being too limited, considering the effort involved.

I believe that a company with 5,000 employees would save about 100,000 baht on their insurance. This isn't that much. To be honest, it is only a small amount, seeing that we would have to invest time, it would be time consuming and complicated. If we can save 100,000 baht but we have to do all these things I wouldn't want to join.

Manager, large nonparticipating company

The interviews with managers confirmed to researchers that the incentive of a 10 percent premium reduction had not provided sufficient motivation to outweigh the financial costs of joining ASO, among participants and nonparticipants alike. Opinions varied as to whether a larger incentive could have provided additional motivation for ASO recruitment. More than half (55 percent) of managers whose companies joined agreed that a greater financial incentive would be helpful, but a notably lower level of 40 percent of nonjoining managers gave the same answer, indicating that a substantial remnant remained unattracted by the additional financial incentive.

None of the company mangers questioned indicated that the entitlement to a certificate had been the reason why they had joined ASO. Managers indicated that their companies would be happy to receive the certificate, but alone it did not provide sufficient motivation for participation.

I see the ASO certificate as an outcome of being involved in the project. But if you ask me personally if the ASO certificate was a motivation to join ASO, I would have to say no.

Manager, large ASO participating company

Managers of participating and nonparticipating companies alike viewed the certificate as a potential endorsement of their company's concern for the wellbeing of their employees and their willingness to help society. One manager of a small company that joined ASO, referring to the certificate, stated that he hoped:

...that businesses that contact us would see us as a good company. That we would be seen as being believable, that we have good working conditions, that we care for the health of our employees. So if we get it, it would be good, others would see us at taking care of our employees' health. 
Manager comments indicated that in order for the ASO certificate to be distinguishable from many other certificates offered to private enterprises, high-profile backing from a well-known and important person or institution was required.

On the question of certificates our hotel has so many that I do not know where to put them. If it is not a certificate for the environment, it is for service, or one that comes from guests, from the Thai Tourist Authority, from our parent company, or recommendations from magazines. I am not interested in the certificate unless it came from someone really important like the UN or someone from the royal family that is interested in this topic.

Manager, large ASO participating company

Reasons why companies did not join ASO

Researchers asked managers of nonparticipating companies why they had declined to become involved. The main reasons cited were inconvenience and lack of interest in the scheme, each mentioned by almost 40 percent of respondents (Figure 6). The time and personnel requirements of administering the complicated procedural requirements of the project were specifically mentioned as disincentives.

I can't remember exactly about the details of the project, but I remember we had to complete all these questionnaires. Also, I remember that the process of the project was too complicated. We had to do all these things, thus it was too complicated for us. If you ask did I see the benefit of the project I would have to say yes, but we had to do all these tasks, as if we didn't have any other work to do.

Manager, large nonparticipating company

\section{Figure 6 Reasons why companies did not join ASO}

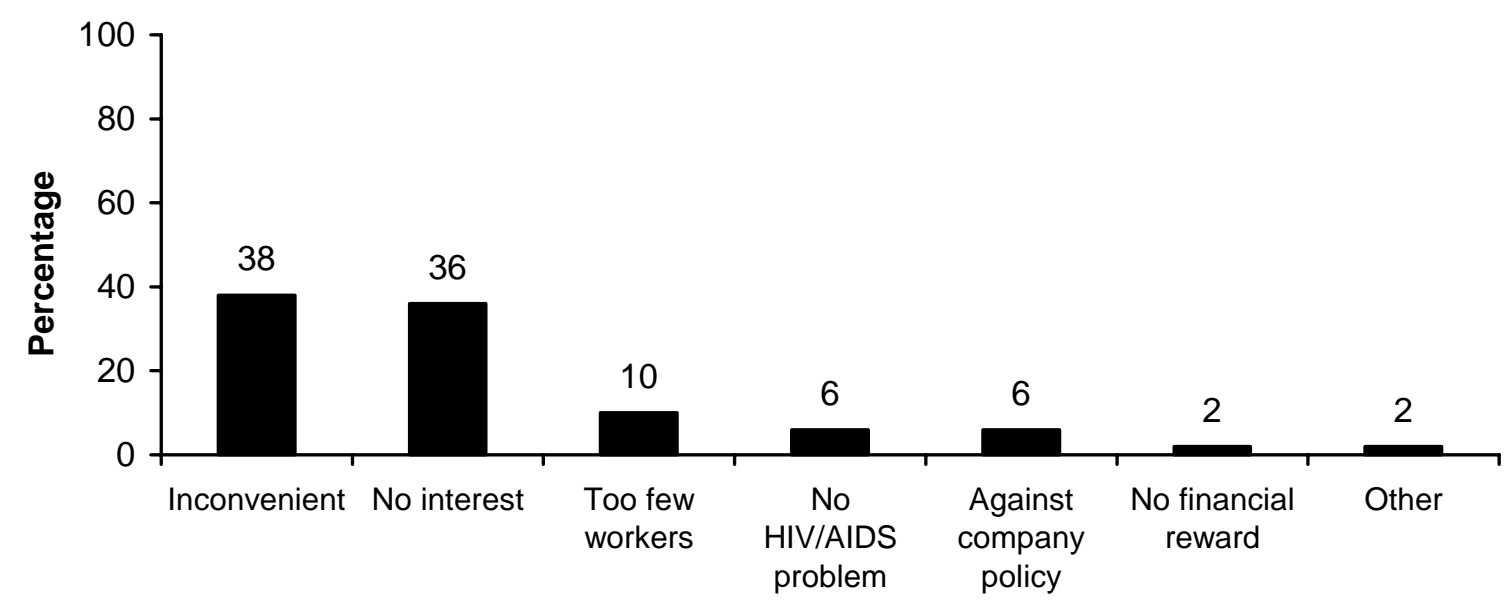

Note: $\quad n=769$ responses based on 732 companies that decided not to join, multiple responses allowed. 


\section{Hgrizons}

Interviews with managers indicated that time concerns were a substantial worry for companies choosing not to participate. Managers were asked whether they had had problems making time for HIV/AIDS workplace activities at the time that the ASO project was being promoted: 62 percent of nonparticipating managers indicated that they had indeed faced such problems, significantly more than those that did join, of whom 44 percent reported time management difficulties $(\mathrm{p}=.006)$.

To be honest, we have so much to do. For example, last year I covered 170 different topics during the training. Each year there are 365 days and I spent two days for each topic, and for some topics I have to spend extra time. Thus, I decided not to join the project; if I had joined it would have meant that I wouldn't be able to do many other things.

Manager, large nonparticipating company

The second most commonly cited reason for nonparticipation was a lack of interest in the project, mentioned by 36 percent of nonparticipating companies. One managing director of a large company that did not join ASO felt that there was no need to introduce HIV/AIDS workplace activities because "HIV employees just quit when they are unable to work and that there is no undue workplace conflict." A further 6 percent of company managers indicated that they did not think that their employees faced an HIV/AIDS problem or engaged in activities that placed them at risk of the disease. The lack of interest and knowledge about the risks of employees and the responsibilities of employers, even in these areas of relatively high HIV prevalence, indicates a need for widespread education programs among high-level company management.

I don't believe that our employees are at risk of HIV/AIDS. First, our employees are well educated and second, we are providing HIV/AIDS information twice a year. Thus the percentage of employees at risk would be very low.

Manager, large nonparticipating company

One in ten managers stated that the small size of their company made an investment in joining the ASO not worthwhile in terms of the ability to locate and assign resources (time, money, responsible personnel) to the project.

The main reason why we didn't join was that we have a very small workforce. We only have 17 workers and that includes me.

Manager, small nonparticipating company

A further 6 percent of companies did not join ASO because its requirements were in direct contravention of their existing policies (e.g., HIV testing of employees). A manager of a large company that did not join ASO indicated that despite the pressure on his company to change their policy, they were unwilling to do so:

I feel very awkward when I go to meetings and meet NGO workers. Sometimes they interrogate me [about the key policies], as if I was a criminal. I tell these NGO workers that we can't write the policy, as they would want. Such a policy would be more suitable for a foundation, not for a business. I feel that if we look at it in a business way, the way we treat our employees is good. 


\section{Levels of participation}

\section{Company characteristics}

The total number of companies invited to join ASO was 857. Participation in the first round of data collection was 125 companies (15 percent of those invited to join). Researchers used the recruitment and participation datasets to determine which factors were associated with higher levels of company participation (Table 4).

Higher levels of participation were observed among service and hotel companies than among factories or among professional or commercial firms. This association may have been due to the strong personal contacts of the TBCA board with international hotel chains, making it easier to contact and convince the hotels to participate in this project. Alternatively, perhaps employees in these industries have more direct involvement with clients, and thus managers might be more concerned about presenting a good public image to clients.

Researchers investigated a possible association between company size and participation level, hypothesizing that larger companies might be associated with higher participation than smaller companies, who face a proportionately higher cost burden. The maximum insurance reduction represented a constant 10 percent off premiums for companies of all sizes, but the burden per worker of accompanying implementation costs of the workplace HIV/AIDS policies was greater on smaller companies with less-developed organizational infrastructures. However, this hypothesis was not definitively found to be supported by the data in Table 4 (or additional analysis ${ }^{5}$ ). Among AIA client companies, there was a statistically significant relationship between ASO participation levels and the number of employees insured by AIA, in that companies with more insured employees were more likely to participate. Although the percentage reduction remained constant, the absolute value of the financial incentive was greater for companies with more insured employees, which may have represented a motivation for larger companies to join ASO.

ASO participation was significantly higher in Chiang Mai than Bangkok, possibly due to confounding by the longstanding personal relationships between TBCA staff and provincial businesses. This association might also reflect the greater ease of communication and travel that exists in Chiang Mai, a much smaller city than the capital Bangkok. Another possible explanation is that the high HIV prevalence rate in northern Thailand could have motivated companies in Chiang Mai to act.

\footnotetext{
${ }^{5}$ Mean company size among 121 companies that joined was 607 employees, compared to 422 employees for 671 that did not join; $\mathrm{p}>0.05$ by independent sample t-test.
} 


\section{Hgrizons}

Table 4 Company participation in ASO, by company characteristics

\begin{tabular}{|c|c|c|c|}
\hline Company characteristics & $\begin{array}{c}\text { Companies } \\
\text { participating } \\
\%\end{array}$ & $n=857$ & $\begin{array}{c}\text { Significance } \\
\left(\text { Pearson } \text { chi }^{2}\right)\end{array}$ \\
\hline Service/hotel & 33 & 114 & $<.001^{* \star}$ \\
\hline Professional & 18 & 28 & \\
\hline Commercial & 14 & 91 & \\
\hline Factory & 12 & 567 & \\
\hline 1-100 employees & 10 & 274 & 0.06 \\
\hline 101-300 employees & 15 & 253 & \\
\hline > 301 employees & 19 & 330 & \\
\hline 1-300 employees insured with AIA & 22 & 91 & $.005^{* *}$ \\
\hline 300 plus employees insured with AIA & 46 & 44 & \\
\hline Bangkok area & 11 & 706 & $<.001^{* *}$ \\
\hline Chiang Mai area & 33 & 151 & \\
\hline Head office & 18 & 468 & $.003^{* *}$ \\
\hline Branch/sub-contractor & 11 & 352 & \\
\hline Thai ownership ${ }^{a}$ & 55 & 94 & $.001^{* *}$ \\
\hline Joint venture companies ${ }^{a}$ & 33 & 119 & \\
\hline International companies ${ }^{\mathrm{a}}$ & 24 & 17 & \\
\hline AIA member only & 26 & 106 & $<.001^{* *}$ \\
\hline TBCA member only & 11 & 165 & \\
\hline Member of both AIA and TBCA & 41 & 29 & \\
\hline Not a member of either & 12 & 528 & \\
\hline $\begin{array}{l}\text { Previous experience with private } \\
\text { insurance (any kind) }\end{array}$ & 16 & 463 & 682 \\
\hline Life insurance & 19 & 224 & .091 \\
\hline Health insurance & 16 & 127 & .863 \\
\hline Accident insurance & 8 & 160 & $.001^{\star *}$ \\
\hline Group insurance & 14 & 212 & 169 \\
\hline
\end{tabular}


Analysis of both the recruitment and participation datasets indicated that participation was significantly higher among Thai-owned than internationally owned companies and at head offices rather than at branch offices. These associations may be due to the fact that TBCA staff found it easier to communicate the advantages of ASO in Thai with local senior Thai managers, or because the decision to evaluate joining ASO may have been more complex in companies where the decision-making powers were located outside the country or region.

A small number of companies that were TBCA members with AIA life insurance had high participation levels, reflecting the efforts made at the start of the initiative to contact and develop relationships with both AIA members, who could take advantage of the insurance premium reduction, and TBCA members with whom staff had preexisting contacts.

There was no obvious relationship between companies' participation and their previous experience with other insurance schemes. Participation was not found to be associated with the sex ratio of employees, the balance of skilled and unskilled workers, or the position of the decision maker approached.

\section{Managers' views}

Researchers also explored the links between company commitment to HIV/AIDS issues, managers' perceptions of the ASO contact process, and eventual company participation. The surveys included questions about a wide range of issues regarding managers' views of HIV/AIDS, workplace activities, and the ASO contact process. Only those aspects found to be significantly associated with participation are shown in Tables 5 and 6.

Participation was highest among companies whose managers expressed personal involvement in HIV/AIDS issues and companies that had already demonstrated commitment to previous HIV/AIDS activities. ASO participation was significantly higher among companies with any previous history of undertaking workplace HIV/AIDS than among those to whom HIV/AIDS activities represented a new venture. Managers who believed that HIV/AIDS is an issue for companies to be involved in and those who felt that HIV/AIDS workplace activities are worth the cost were more likely to decide that their companies should participate in ASO than were managers from other companies. Results also indicate the importance of establishing a solid and credible relationship with company managers. 


\section{Hgrizons}

Table 5 Company participation in ASO, by company activities

\begin{tabular}{|c|c|c|c|c|c|c|}
\hline \multirow[t]{2}{*}{ Company characteristics } & \multicolumn{2}{|c|}{$\begin{array}{l}\text { Companies } \\
\text { participating }\end{array}$} & \multicolumn{2}{|c|}{$\begin{array}{c}\text { Companies } \\
\text { not } \\
\text { participating }\end{array}$} & \multirow[b]{2}{*}{$\mathbf{N}$} & \multirow[t]{2}{*}{$\begin{array}{c}\text { Significance } \\
\text { (Pearson } \\
\left.\text { chi }^{2}\right)\end{array}$} \\
\hline & $\%$ & $\mathbf{n}$ & $\%$ & $\mathbf{n}$ & & \\
\hline $\begin{array}{l}\text { Undertaken AIDS activities in last } \\
3 \text { years }\end{array}$ & 57 & 54 & 34 & 46 & 100 & $<.001^{* \star}$ \\
\hline Did not undertake such activities & 43 & 40 & 66 & 90 & 130 & \\
\hline Total & & 94 & & 136 & 230 & \\
\hline $\begin{array}{l}\text { Undertook AIDS activities in last } \\
\text { year }\end{array}$ & 47 & 44 & 31 & 42 & 86 & $.016^{\star}$ \\
\hline Did not undertake such activities & 53 & 50 & 69 & 93 & 143 & \\
\hline Total & & 94 & & 135 & 229 & \\
\hline
\end{tabular}

Data source: Company participation data

The qualitative research revealed that inappropriate aspects of the contact process negatively influenced company managers. Although some of these managers represented companies that eventually went on to join ASO, other managers were discouraged by these factors and refrained from joining:

From the beginning when we were contacted by TBCA, asking us to undertake the questionnaire, we weren't impressed with how they contacted us. The contacts were time consuming, which made us wonder whether the project would be successful as well as making us believe that TBCA wasn't serious about the project. We couldn't see what the results of the projects would be. We weren't sure what the purpose of the project was, whether it was simply to promote AIA, or a way for someone to make money.

Manager, small ASO participating company

I didn't like the way that they contacted us. The fax wasn't clear; it was unreadable. I couldn't understand what I was reading. It wasn't two-way communication. After I received the fax I didn't hear anything from them for a number of months. It just wasn't good manners; you have to give someone a call before you send them a fax. Once sending us a fax you have to send someone to contact us. A project like this you have to have close contact, isn't that the case. 
Table 6 Participation and managers' perceptions about HIV/AIDS and ASO

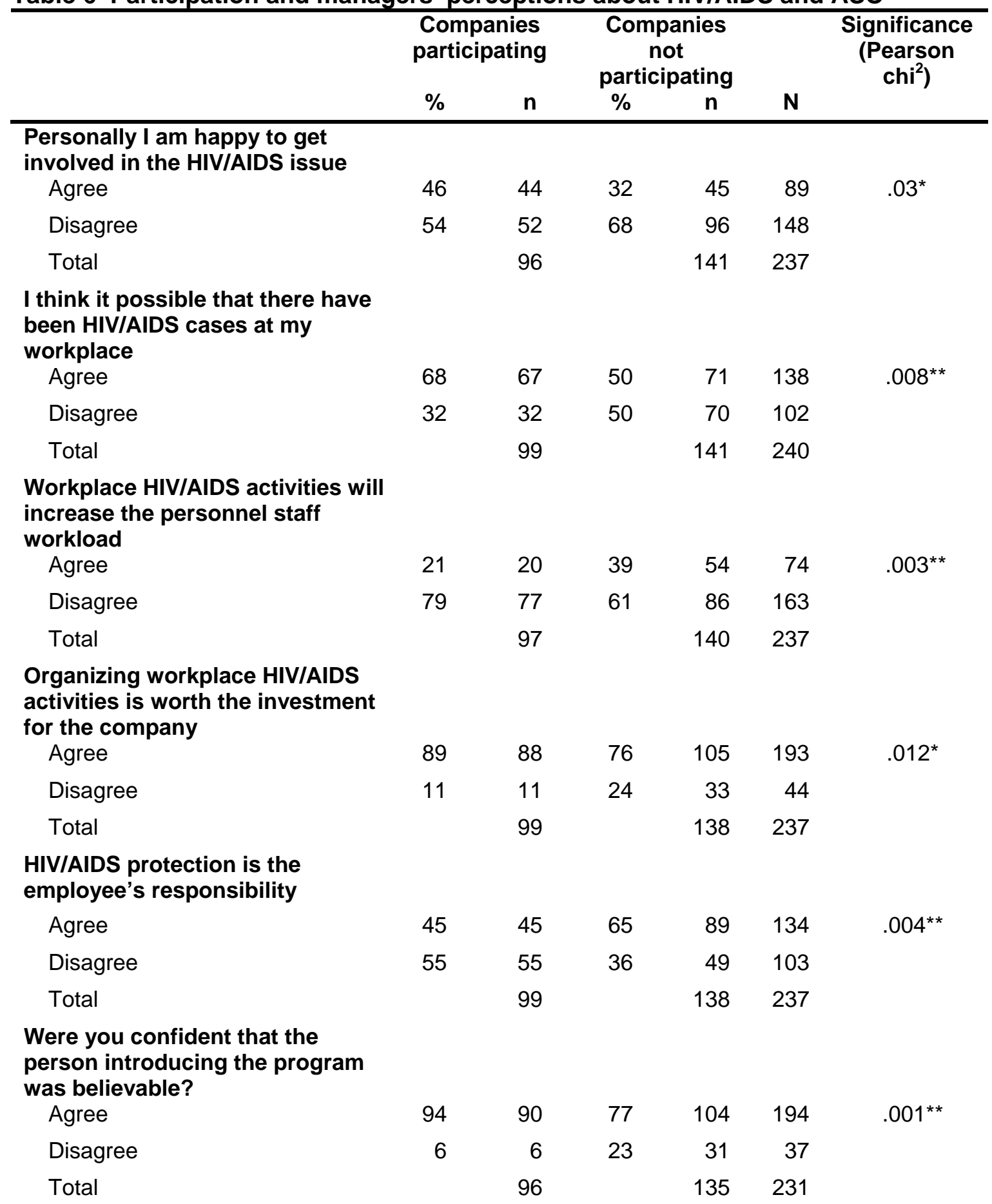

Data source: Company participation data 


\section{Hgrizons}

\section{Workplace I mpact}

\section{Accreditation system}

The scoring system, based on previous research conducted by TBCA, was designed to take into account both the existence of a policy within company management circles (whether formally documented or informally acknowledged) and its public announcement to employees.

Companies were first scored on their compliance with the three key anti-discriminatory workplace policies that determined the entitlement to the financial incentive and certificate:

- No blood tests for job applicants.

- No blood tests for employees.

- Allowing people known to be HIV-positive to continue working.

Companies whose policies did not reach these minimum measures required were not entitled to the financial incentives or the certificate.

Researchers also investigated companies' compliance with eight additional policy and program areas, for which they could gain additional credit:

- Announcing the key anti-discriminatory policies to employees.

- Maintaining employee confidentiality.

- Providing assistance to HIV-positive employees.

- Providing staff training on HIV/AIDS.

- Disseminating HIV/AIDS information (leaflets, etc.) to employees.

- Promoting condoms among employees.

- Supplementary HIV/AIDS activities (e.g., working committee / peer group / counselor, reimbursement of medical expenses related to STIs).

- Being involved in community HIV/AIDS activities.

Scores taking into account all these multiple dimensions were calibrated to a possible maximum total of 100 points. Maximum scores in each area are shown in Table 8.

\section{Change in total scores}

Using data from the company evaluations before and after implementation of the policies, researchers found that 82 percent of the participating companies had improved upon their total accreditation score, demonstrating real improvements in HIV/AIDS policies at the workplace. The mean accreditation score in round 1 was 37, improving to 51 in round $2(\mathrm{p}<.001$, independent sample t-test). Figure 7 shows the distribution of accreditation scores achieved in the first and second round, indicating that companies' policies improved significantly. 
Figure 7 Distribution of company evaluation scores, by round

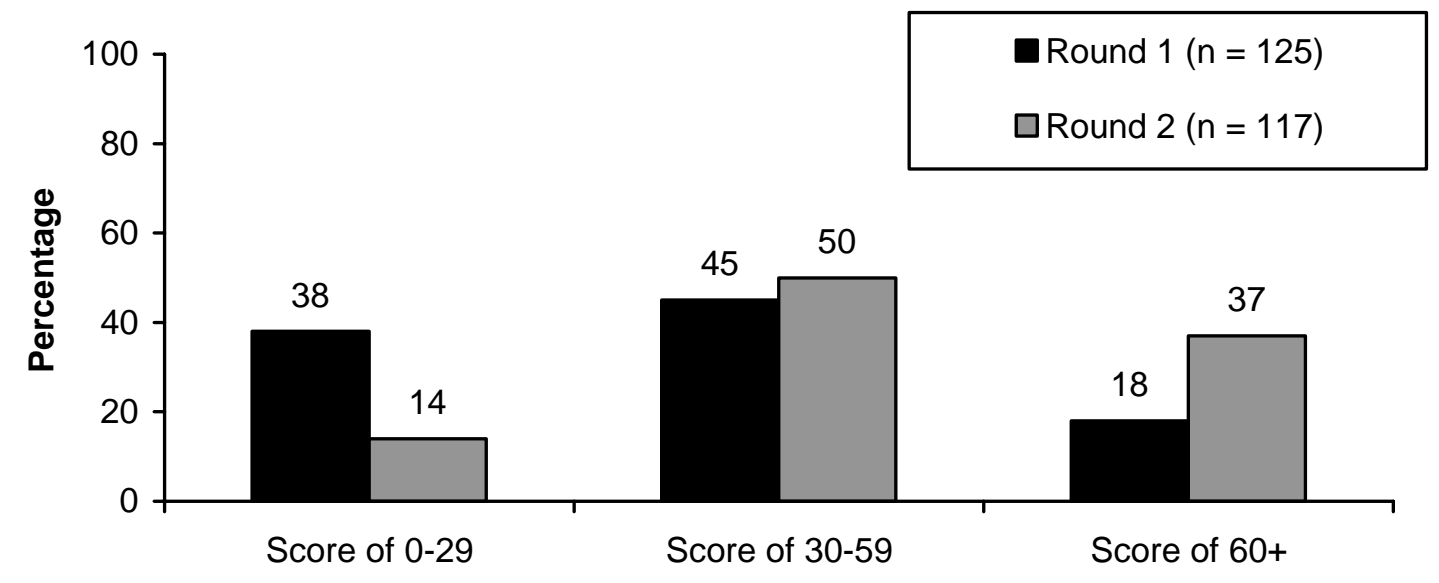

\section{Changes in compliance with the three key policies}

The number of companies with policies directly contravening the three basic requirements of ASO decreased between the first and second round (Table 7), although only one of these policy measures showed statistical significance. The number of companies with explicit requirements for blood tests from employees and job applicants, as well as the number of companies refusing to allow HIV-positive employees to continue working, all decreased between rounds. Several companies that joined ASO but were found to be noncompliant by the second round lost their entitlement to a rate reduction and certificate (but continued to be included in the analysis). Although policy improvements were evident, many companies still had not documented their implementation of these measures, so further room for improvement clearly remains.

\section{Changes in compliance in the eight additional policy areas}

Participating companies recorded significant improvements in all areas, shown in Table 8.

Improvements of the greatest magnitude were observed in the scores for assistance to HIV-positive employees and supplementary HIV/AIDS activities. 
Table 7 Key policy compliance, by round

\begin{tabular}{|c|c|c|c|c|c|}
\hline & \multicolumn{2}{|c|}{$\begin{array}{c}\text { Round 1 } \\
n=125\end{array}$} & \multicolumn{2}{|c|}{$\begin{array}{c}\text { Round } 2 \\
n=117\end{array}$} & \multirow[t]{2}{*}{$\begin{array}{l}\text { Significance } \\
\left(\text { Pearson } \text { chi }^{2}\right)\end{array}$} \\
\hline & $\mathbf{n}$ & $\%$ & $\mathbf{n}$ & $\%$ & \\
\hline \multicolumn{6}{|l|}{ Blood tests for applicants } \\
\hline Required $^{\mathrm{a}}$ & 26 & 21 & 14 & 12 & .064 \\
\hline Not required - unwritten & 85 & 68 & 83 & 71 & \\
\hline Not required - written & 14 & 11 & 20 & 17 & \\
\hline \multicolumn{6}{|l|}{ Blood tests for employees } \\
\hline Required $^{\mathrm{a}}$ & 12 & 10 & 4 & 3 & .053 \\
\hline Not required - unwritten & 96 & 77 & 90 & 77 & \\
\hline Not required - written & 17 & 14 & 23 & 20 & \\
\hline \multicolumn{6}{|c|}{ HIV-positive continue working } \\
\hline Not allowed ${ }^{\mathrm{a}}$ & 23 & 18 & 5 & 4 & $.001^{* *}$ \\
\hline Allowed - unwritten & 88 & 70 & 95 & 80 & \\
\hline Allowed - written & 14 & 11 & 18 & 15 & \\
\hline
\end{tabular}

Table 8 Accreditation scores, by policy area

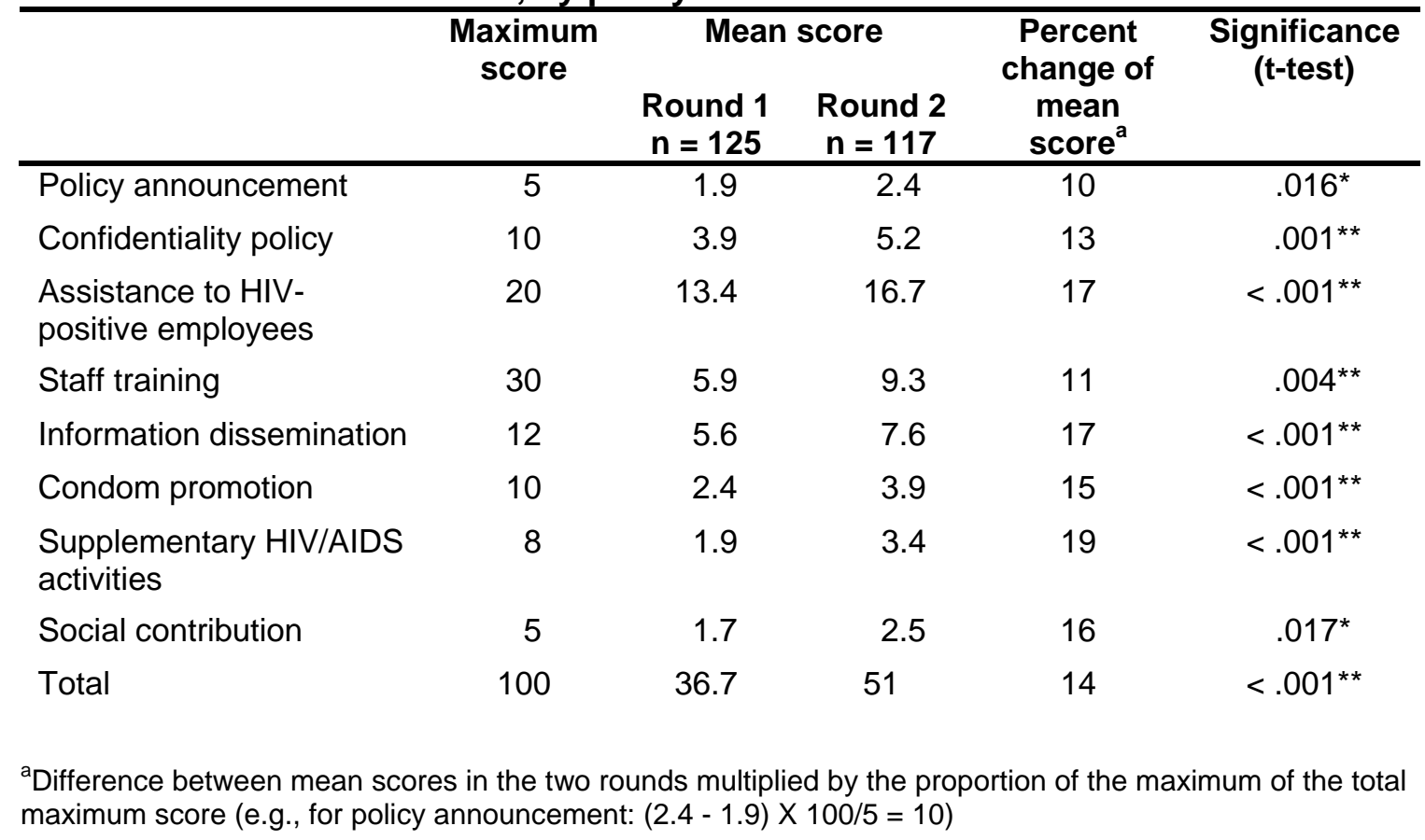




\section{Policy announcement}

The maximum score of five points was awarded to companies at which the three key policies had been written down and announced to all their employees. The mean score for policy announcement increased from 1.9 in round 1 to 2.4 in round 2, out of a maximum of 5 points. By the second round, all except two of the companies with written key policies had announced them to all of their employees.

Table 9 below shows the extent to which companies with unwritten policies informed their employees of their implementation. Among companies with unwritten policies there was no statistically significant improvement in awareness among employees. However, for each of the key policies there was a marked increase in communication of the policy at least to the managerial staff. Further, there was a marked decrease among companies at which only the policymaker knew of the existence of those unwritten policies.

Table 9 Knowledge of key policies in companies with unwritten HIV/AIDS policies

\begin{tabular}{lccc}
\hline Policy & $\begin{array}{c}\text { Round 1 } \\
\%\end{array}$ & $\begin{array}{c}\text { Round 2 } \\
\%\end{array}$ & $\begin{array}{c}\text { Significance } \\
\text { (Pearson chi }^{2} \text { ) }\end{array}$ \\
\hline No blood tests for applicants & $\mathrm{n}=82$ & $\mathrm{n}=83$ & $<.001^{* *}$ \\
All employees are told & 23 & 28 & \\
Just managers are told & 37 & 68 & \\
Just responsible officers are told & 5 & 0 & $<.001^{* *}$ \\
Only policymakers know & 35 & 5 & \\
No blood tests for employees & $\mathrm{n}=94$ & $\mathrm{n}=90$ & \\
All employees are told & 48 & 47 & \\
Just managers are told & 27 & 48 & \\
Just responsible officers are told & 7 & 3 & \\
Only policymakers know & 18 & 2 & \\
HIV-positive employees allowed to & $\mathrm{n}=86$ & $\mathrm{n}=94$ & \\
continue to work & & & \\
All employees are told & 15 & 12 & \\
Just managers are told & 49 & 80 & \\
Just responsible officers are told & 12 & 5 & \\
Only policymakers know & 24 & 3 &
\end{tabular}

Note: In both the variables "No blood tests for applicants" and "No blood tests for employees" there is a cell with fewer than five cases. 


\section{Hgrizons}

\section{Confidentiality}

A maximum score of 10 points was awarded to companies with policies stating that no employee needed to report his or her HIV status and ensuring confidentiality to employees who revealed their status in order to change positions.

Between the two rounds there was an increase in the number of companies that had a policy to maintain confidentiality, rising from two-thirds of all the companies to 88 percent. The mean evaluation score for confidentiality increased from 3.9 in round 1 to 5.2 in round 2, out of a maximum of 10 points.

\section{Assistance to HIV-positive employees}

A maximum score of 20 points was awarded to companies with mechanisms in place to provide assistance to HIV-positive employees, such as flexible job requirements, nonsegregation of HIVpositive employees, and the intention to maintain the benefits of HIV-positive people at the same level of other staff.

Table 8 above showed that the mean score in this area increased significantly during the period of the intervention, from 13.4 in round 1 , to 16.7 in round 2 , out of a maximum of 20 points. The number of companies with policies in place for the assistance of HIV-positive employees rose from 86 percent of the companies to 97 percent during the study. Some of the improved policies put in place included commitments not to reduce regular benefits to HIV-positive employees; enabling HIV-positive employees to move positions to suit their health; paying the employee's extra costs, such as medical costs and social insurance funds until the person's death; and permitting HIVpositive employees to work in the same location as HIV-negative workers (Table 10). By the second round of the survey, 100 percent of companies had instituted policies not to reduce regular benefits to HIV-positive employees and to ensure that HIV-positive employees have the same rights as other workers. 
Table 10 Details of company policies to assist HIV-positive employees

\begin{tabular}{|c|c|c|c|}
\hline HIV/AIDS policies in the workplace to: & $\underset{\%}{\text { Round } 1}$ & $\underset{\%}{\operatorname{Round} 2}$ & $\begin{array}{c}\text { Significance } \\
\left(\begin{array}{c}\text { Pearson } \\
\left.\text { chi }^{2}\right)\end{array}\right.\end{array}$ \\
\hline & $\mathrm{n}=125$ & $\mathrm{n}=117$ & \\
\hline Assist HIV-positive employees (generally) & 86 & 97 & $.001^{* *}$ \\
\hline $\begin{array}{l}\text { Among companies with workplace policies to } \\
\text { assist HIV-positive employees }\end{array}$ & $\mathrm{n}=107$ & $n=114$ & \\
\hline Maintain benefits to HIV-positive employees & 99 & 100 & .301 \\
\hline $\begin{array}{l}\text { Affirm that HIV-positive employees have the same } \\
\text { rights as other workers }\end{array}$ & 94 & 100 & $.010^{\star}$ \\
\hline $\begin{array}{l}\text { Enable HIV-positive employees to move posts to suit } \\
\text { their health }\end{array}$ & 79 & 96 & $<.001^{* *}$ \\
\hline $\begin{array}{l}\text { Enable HIV-positive employees to work in the same } \\
\text { location as HIV-negative workers }\end{array}$ & 88 & 97 & $.006^{* *}$ \\
\hline $\begin{array}{l}\text { Allow HIV-positive employee to leave work based on } \\
\text { doctor's advice }\end{array}$ & 94 & 96 & .480 \\
\hline The five policies above cover other chronic diseases & 86 & 99 & $<.001^{* *}$ \\
\hline $\begin{array}{l}\text { Keep HIV-positive employee in employment as long } \\
\text { as possible }\end{array}$ & 92 & 97 & .056 \\
\hline $\begin{array}{l}\text { Give extra work if the HIV-positive employee wants } \\
\text { to earn extra income }\end{array}$ & 4 & 3 & .639 \\
\hline $\begin{array}{l}\text { Pay all benefits to the HIV-positive employee if she } \\
\text { or he is dismissed }\end{array}$ & 45 & 43 & .779 \\
\hline $\begin{array}{l}\text { Pay extra costs, such as medical costs and social } \\
\text { insurance funds until the person's death }\end{array}$ & 51 & 70 & $.003^{* *}$ \\
\hline $\begin{array}{l}\text { Help affected family with education scholarship for } \\
\text { their children or to allow spouse to work }\end{array}$ & 14 & 19 & .293 \\
\hline
\end{tabular}

\section{Staff training}

The staff training score carried a maximum of 30 points based on the proportion of staff who received HIV/AIDS-related training in the past year and in the last three years.

During the period of the intervention, the mean score improved from 5.9 to 9.3, out of a maximum of 30 points (Table 8). The distribution of companies reporting the proportion of employees trained on HIV/AIDS in the last year improved significantly by the second round of the survey (Table 11). 


\section{Table 11 Employees receiving HIV/AIDS training}

\begin{tabular}{|c|c|c|c|}
\hline & $\underset{\%}{\operatorname{Round} 1}$ & $\begin{array}{c}\text { Round } 2 \\
\%\end{array}$ & $\begin{array}{c}\text { Significance } \\
\left(\text { Pearson } \text { chi }^{2}\right)\end{array}$ \\
\hline Employees trained on HIV/AIDS in last year & $n=122$ & $n=116$ & \\
\hline No one was trained & 64 & 54 & $.023^{*}$ \\
\hline Up to 25 percent of employees were trained & 25 & 39 & \\
\hline $\begin{array}{l}\text { More than } 25 \text { percent of employees were } \\
\text { trained }\end{array}$ & 12 & 23 & \\
\hline $\begin{array}{l}\text { Employees trained on HIV/AIDS in last } \\
\text { three years }\end{array}$ & $\mathrm{n}=122$ & $\mathrm{n}=114$ & \\
\hline No one was trained & 54 & 47 & .445 \\
\hline Up to 25 percent of employees were trained & 25 & 25 & \\
\hline $\begin{array}{l}\text { More than } 25 \text { percent of employees were } \\
\text { trained }\end{array}$ & 21 & 28 & \\
\hline
\end{tabular}

\section{Information dissemination}

Information dissemination scores were calculated from the number and frequency of activities conducted. Two points were awarded for each method used to disseminate information to their employees (including brochures, calendars, posters, notice boards, exhibitions, a devoted column in the company magazine, announcements through the intercom, videos, and in-house information centers).

The mean score for the two rounds increased from 5.6 to 7.6, out of a maximum of 12 points (Table 8). The proportion of companies that had campaigns to increase HIV/AIDS knowledge in the last year increased significantly: from 78 percent at round 1 to 93 percent by the second survey (Table 12). Among these companies, information dissemination activities that increased in popularity included leaflet distribution, integrating HIV/AIDS information into company meetings and on orientation days, and broadcasting HIV/AIDS information on company public address (PA) systems or videos. 
Table 12 Companies disseminating HIV/AIDS information

\begin{tabular}{|c|c|c|c|}
\hline & $\underset{\%}{\text { Round } 1}$ & $\underset{\%}{\text { Round } 2}$ & $\begin{array}{l}\text { Significance } \\
\left(\text { Pearson } \text { chi }^{2}\right)\end{array}$ \\
\hline & $n=125$ & $\mathrm{n}=117$ & \\
\hline \multirow{2}{*}{$\begin{array}{l}\text { Company campaign to increase HIV/AIDS } \\
\text { knowledge in last year }\end{array}$} & 78 & 93 & $.001^{* \star}$ \\
\hline & $\mathrm{n}=98$ & $n=109$ & \\
\hline Distributed HIV/AIDS leaflets & 69 & 92 & $<.001^{\star *}$ \\
\hline Used boards/posters & 90 & 91 & .786 \\
\hline HIV/AIDS exhibition & 28 & 40 & .059 \\
\hline HIV/AIDS column in company journal & 19 & 14 & .263 \\
\hline $\begin{array}{l}\text { Broadcast HIV/AIDS information on company PA } \\
\text { system or showed videos to employees }\end{array}$ & 20 & 33 & $.046^{*}$ \\
\hline HIV/AIDS center & 10 & 10 & .961 \\
\hline $\begin{array}{l}\text { Integrated HIV/AIDS information into special } \\
\text { company events }\end{array}$ & 30 & 39 & .151 \\
\hline $\begin{array}{l}\text { Integrated HIV/AIDS information into company } \\
\text { meetings and on orientation days }\end{array}$ & 35 & 57 & $.001^{* \star}$ \\
\hline $\begin{array}{l}\text { Organized HIV/AIDS activities with other } \\
\text { organizations }\end{array}$ & 24 & 27 & .530 \\
\hline Visited employees with AIDS & 26 & 23 & .639 \\
\hline
\end{tabular}

\section{Condom promotion}

Condom promotion scores were calculated from the number of condom training sessions, condom demonstrations, and condoms distributed to employees and carried a maximum score of ten points.

The mean score rose significantly, from 2.4 at round 1 to 3.9 at round 2, out of a maximum of 10 points (Table 8). Companies promoting condoms at the workplace increased from just over half in round 1 to three-quarters of the companies in round 2 (Table 13). Among these, the proportion of companies distributing condoms at the workplace increased from 89 to 99 percent, which was statistically significant. 
Table 13 Companies with condom promotion activities

\begin{tabular}{|c|c|c|c|}
\hline & $\underset{\%}{\text { Round } 1}$ & $\begin{array}{c}\text { Round } 2 \\
\%\end{array}$ & $\begin{array}{l}\text { Significance } \\
\left(\text { Pearson } \mathrm{chi}^{2}\right)\end{array}$ \\
\hline & $n=125$ & $\mathrm{n}=117$ & \\
\hline Condom promotion & 53 & 75 & $<.001^{\star \star}$ \\
\hline Of these... & $\mathrm{n}=65$ & $\mathrm{n}=88$ & \\
\hline Taught condom use & 37 & 43 & .436 \\
\hline Distributed condoms & 89 & 99 & $.008^{\star \star}$ \\
\hline Sold condoms & 8 & 13 & .337 \\
\hline
\end{tabular}

Supplementary HIV/AIDS activities

Supplementary HIV/AIDS activities at the workplace carried a maximum score of eight points. Two points were awarded for each of the following activities: having a company HIV/AIDS working committee, HIV peer group, or HIV counselor, and allowing employees to be reimbursed for medical expenses related to STIs.

Scores in this area increased from 1.9 to 3.4, out of a maximum of 8 points (Table 8). There were significant improvements in the proportion of companies with active HIV/AIDS working groups, with HIV/AIDS counselors, and companies allowing employees to file reimbursement claims for STD treatment from the company's health budget (Table 14).

Table 14 Companies with supplementary HIV/AIDS activities

\begin{tabular}{lccc}
\hline & $\begin{array}{c}\text { Round 1 } \\
\mathbf{n = 1 2 5} \\
\%\end{array}$ & $\begin{array}{c}\text { Round 2 } \\
\mathbf{n = 1 1 7} \\
\%\end{array}$ & $\begin{array}{c}\text { Significance } \\
\text { (Pearson }^{2} \mathbf{~}^{2} \text { ) }\end{array}$ \\
\hline Active HIV/AIDS working group & 18 & 31 & $.016^{*}$ \\
Have HIV/AIDS volunteer & 20 & 21 & .793 \\
Have HIV/AIDS counselor & 43 & 74 & $<.001^{* *}$ \\
Allow employees to claim STI treatment & 16 & 42 & $<.001^{* *}$
\end{tabular}

\section{Social contribution}

Researchers initially aimed to represent company expenditure on community HIV/AIDS activities in relation to annual income, but were unable to acquire complete records of company incomes from either the Stock Exchange of Thailand or the Ministry of Industry. Instead, companies were awarded a dichotomous score of either five or zero to reflect whether or not they were making any kind of contributions (cash or in-kind) to the wider community on HIV/AIDS issues. 
Mean scores in this area increased from 1.7 in round 1 to 2.5 in round 2, out of a maximum of 5 points (Table 8), as the proportion of companies claiming to be involved in HIV/AIDS community activities increased from 36 to 50 percent (Table 15). Meanwhile, simultaneous declines were observed among companies donating money for HIV/AIDS community activities and among companies providing expenses for education or new businesses to family members of HIV-positive employees. Significant improvements were observed for "other" community activities, including donating company products to HIV/AIDS organizations.

\section{Table 15 Percent of companies involved in community activities related to} HIV/AIDS

\begin{tabular}{|c|c|c|c|}
\hline & $\underset{\%}{\operatorname{Round} 1}$ & $\underset{\%}{\operatorname{Round} 2}$ & $\begin{array}{c}\text { Significance } \\
(\text { Pearson } \\
\left.\text { chi }^{2}\right)\end{array}$ \\
\hline & $n=125$ & $n=125$ & \\
\hline \multirow{2}{*}{$\begin{array}{l}\text { Was your company involved in HIV/AIDS } \\
\text { community activities? }\end{array}$} & 36 & 50 & $.033^{*}$ \\
\hline & $\mathrm{n}=45$ & $\mathrm{n}=58$ & \\
\hline Donated money to PLHA & 34 & 35 & .903 \\
\hline Donated money for HIV/AIDS community activities & 21 & 7 & $.042^{*}$ \\
\hline Organized fund-raising events for PLHA & 9 & 8 & .934 \\
\hline $\begin{array}{l}\text { Assisted in educational expenses and helped } \\
\text { establish new businesses for family members } \\
\text { of HIV-positive employees }\end{array}$ & 18 & 7 & .086 \\
\hline Other contributions & 12 & 50 & $<.001^{* *}$ \\
\hline
\end{tabular}

\section{Differences between AIA and non-AIA client companies}

Table 16 shows that at baseline, there were no significant differences between the accreditation scores of companies that were clients of AIA and companies with life insurance policies from other providers (mean scores 39.9 and 35.1, respectively). By round two, the scores of AIA client companies, which had earned a reduction on their life insurance, had improved significantly more than non-clients, who stood to gain no such financial reward (scores of 63.6 and 46.5). Further, AIA client companies spent more money on changing their HIV/AIDS programs and policies than non-AIA clients (see the section on cost-benefit analysis below). These findings suggest that linking the accreditation scheme to reduced insurance premiums provided AIA member companies with a greater incentive to make improvements in workplace HIV/AIDS programs than nonmember companies. As observed above, the financial incentive had not been sufficient to recruit companies to join the program, but companies that were able to gain a financial reward made greater efforts and showed greater improvements once they had already joined. 
Table 16 Company accreditation scores for AIA members and nonmembers

\begin{tabular}{|c|c|c|c|c|c|c|}
\hline & \multicolumn{3}{|c|}{ Round 1} & \multicolumn{3}{|c|}{ Round 2} \\
\hline & $\begin{array}{c}\text { AIA } \\
n=42 \\
\%\end{array}$ & $\begin{array}{c}\text { Non-AIA } \\
\mathrm{n}=83 \\
\%\end{array}$ & Significance & $\begin{array}{c}\text { AIA } \\
n=31 \\
\%\end{array}$ & $\begin{array}{c}\text { Non-AIA } \\
\mathbf{n}=86 \\
\%\end{array}$ & Significance \\
\hline $\begin{array}{l}\text { Low score } \\
0-29\end{array}$ & 41 & 36 & $\begin{array}{c}.260 \\
(\text { Pearson } \\
\left.\text { chi }^{2}\right)\end{array}$ & 7 & 16 & $\begin{array}{l}<.001^{* *} \\
(\text { Pearson } \\
\left.\text { chi }^{2}\right)\end{array}$ \\
\hline $\begin{array}{l}\text { Medium score } \\
30-59\end{array}$ & 36 & 49 & & 16 & 62 & \\
\hline $\begin{array}{l}\text { High score } \\
60 \text {-positive }\end{array}$ & 24 & 15 & & 77 & 22 & \\
\hline Mean & 39.93 & 35.12 & $\begin{array}{l}.201 \\
\text { (t-test) }\end{array}$ & 63.61 & 46.47 & $\begin{array}{l}<.001^{* *} \\
\text { (t-test) }\end{array}$ \\
\hline
\end{tabular}

\section{Employees}

\section{Respondent profile}

Table 17 shows the characteristics of the employees surveyed in the two survey rounds. In round 1 , 9,603 employees completed the SAQ, while in round 2, with fewer participating companies, 7,850 employees did so. Although three quarters of the questionnaire respondents filled in the survey for only one of the rounds, there were no significant differences between the respondents'

sociodemographic characteristics at each round. There were no significant differences overall in the mean duration of employment (67.07 months in round 1 and 67.7 months in round $2, p=.523$

independent sample t-test).

This section analyzes the impact of improved HIV/AIDS workplace policies and program activities on employees, comparing the 94 companies who improved on their accreditation scores to the 20 companies that received a lower score in the second round. Employees from the three companies that did not change their accreditation score over two rounds are not included. 


\section{Table 17 Characteristics of employees}

\begin{tabular}{|c|c|c|c|}
\hline & $\begin{array}{c}\text { Round } 1 \\
\%\end{array}$ & $\underset{\%}{\operatorname{Round} 2}$ & $\begin{array}{l}\text { Significance } \\
\left(\text { Pearson } \mathrm{chi}^{2}\right)\end{array}$ \\
\hline & $n=9,603$ & $\mathrm{n}=7,850$ & \\
\hline \multicolumn{4}{|l|}{ Sex } \\
\hline Male & 51 & 50 & .112 \\
\hline Female & 49 & 50 & \\
\hline \multicolumn{4}{|l|}{ Age } \\
\hline 27 and under & 35 & 36 & .225 \\
\hline $28-34$ & 34 & 33 & \\
\hline 35 and over & 32 & 31 & \\
\hline \multicolumn{4}{|l|}{ Education } \\
\hline Primary & 15 & 14 & .078 \\
\hline High school & 41 & 41 & \\
\hline Vocational & 22 & 22 & \\
\hline University & 22 & 23 & \\
\hline \multicolumn{4}{|l|}{ Marital status } \\
\hline Single & 41 & 42 & .175 \\
\hline Married & 54 & 53 & \\
\hline Divorced & 3 & 3 & \\
\hline Widowed & 2 & 2 & \\
\hline $\begin{array}{l}\text { If you are married or have been } \\
\text { married, do you have children? }\end{array}$ & $n=5,966$ & $n=2,942$ & \\
\hline Yes & 68 & 69 & .324 \\
\hline No & 32 & 31 & \\
\hline
\end{tabular}




\section{Hgrizons}

\section{Knowledge}

Researchers examining employees' knowledge about HIV and risk behaviors detected some small improvements among employees of companies whose scores improved, yet the magnitude of these changes did not exceed a few percentage points (Table 18). Some selected results of questions that covered a wide range of issues regarding employees' knowledge of HIV/AIDS are shown below.

Table 18 Employees' knowledge about HIV/AIDS, by company accreditation score change

\begin{tabular}{|c|c|c|c|c|c|}
\hline \multirow[t]{2}{*}{$\begin{array}{l}\text { Do you think that } \ldots \text { ? } \\
\text { (\% answered yes) }\end{array}$} & \multicolumn{2}{|c|}{$\begin{array}{l}\text { Companies with } \\
\text { improved score }\end{array}$} & \multicolumn{2}{|c|}{$\begin{array}{l}\text { Companies with } \\
\text { worse score }\end{array}$} & \multirow{2}{*}{$\begin{array}{c}\text { Significance } \\
\text { (Pearson } \\
\left.\text { chi }^{2}\right)\end{array}$} \\
\hline & $\%$ & $\mathbf{n}$ & $\%$ & $\mathbf{n}$ & \\
\hline \multicolumn{6}{|c|}{$\begin{array}{l}\text {... the AIDS virus can penetrate } \\
\text { through wounds and organ tissues }\end{array}$} \\
\hline Round 1 & 71 & 7,216 & 71 & 984 & .802 \\
\hline Round 2 & 75 & 6,393 & 71 & 909 & $.008^{\star \star}$ \\
\hline \multicolumn{6}{|c|}{$\begin{array}{l}\ldots \text { the female anatomy places } \\
\text { females at greater risk than males }\end{array}$} \\
\hline Round 1 & 64 & 7,176 & 68 & 983 & $.017^{\star}$ \\
\hline Round 2 & 67 & 6,358 & 60 & 904 & $<.001^{* *}$ \\
\hline \multicolumn{6}{|c|}{$\begin{array}{l}\text {...living with a PLHA poses no or } \\
\text { low risk }\end{array}$} \\
\hline Round 1 & 73 & 7,152 & 67 & 990 & $<.001^{* *}$ \\
\hline Round 2 & 76 & 6,338 & 70 & 890 & $<.001^{\star *}$ \\
\hline \multicolumn{6}{|c|}{$\begin{array}{l}\text {...having multiple sexual partners } \\
\text { poses no or low risk }\end{array}$} \\
\hline Round 1 & 6 & 7,193 & 5 & 980 & .393 \\
\hline Round 2 & 5 & 6,361 & 7 & 900 & .043 * \\
\hline
\end{tabular}

\section{Attitudes}

Tables 19 and 20 and Figure 8 indicate that researchers detected some significant differences in stigmatizing attitudes between employees of companies with improved and deteriorated accreditation scores. However, due to the enormously large sample size, the actual extent of these changes was extremely small and may not have programmatic significance. 
Table 19 Employees' attitudes toward PLHA, by company accreditation score change

\begin{tabular}{|c|c|c|c|c|c|}
\hline \multirow[t]{2}{*}{$\begin{array}{l}\text { Percentage of employees who } \\
\text { believe that... }\end{array}$} & \multicolumn{2}{|c|}{$\begin{array}{l}\text { Companies with } \\
\text { improved score }\end{array}$} & \multicolumn{2}{|c|}{$\begin{array}{l}\text { Companies with } \\
\text { worse score }\end{array}$} & \multirow[t]{2}{*}{$\begin{array}{l}\text { Significance } \\
\left(\text { Pearson } \mathrm{chi}^{2}\right)\end{array}$} \\
\hline & $\%$ & $\mathbf{n}$ & $\%$ & $\mathbf{n}$ & \\
\hline \multicolumn{6}{|c|}{$\begin{array}{l}\text {... they can work in the same room } \\
\text { as PLHA }\end{array}$} \\
\hline Round 1 & 83 & 7,229 & 84 & 989 & .176 \\
\hline Round 2 & 83 & 6,424 & 83 & 904 & .923 \\
\hline \multicolumn{6}{|l|}{$\begin{array}{l}\text {... they can use the same toilet as } \\
\text { PLHA }\end{array}$} \\
\hline Round 1 & 62 & 7,202 & 65 & 988 & .058 \\
\hline Round 2 & 66 & 6,411 & 67 & 903 & .383 \\
\hline \multicolumn{6}{|l|}{... they can eat with PLHA } \\
\hline Round 1 & 65 & 7,192 & 65 & 988 & .792 \\
\hline Round 2 & 67 & 6,409 & 63 & 903 & $.009 * *$ \\
\hline \multicolumn{6}{|l|}{... they can take care of PLHA } \\
\hline Round 1 & 55 & 7,175 & 54 & 988 & .352 \\
\hline Round 2 & 57 & 6,409 & 50 & 897 & $<.001^{* *}$ \\
\hline \multicolumn{6}{|l|}{... they can touch PLHA } \\
\hline Round 1 & 64 & 7,168 & 59 & 982 & $.001^{* *}$ \\
\hline Round 2 & 64 & 6,386 & 58 & 898 & $<.001^{\star *}$ \\
\hline \multicolumn{6}{|c|}{$\begin{array}{l}\text {...their company should not announce } \\
\text { which employees are HIV-positive }\end{array}$} \\
\hline Round 1 & 67 & 7,219 & 73 & 981 & $.001^{* *}$ \\
\hline Round 2 & 72 & 6,388 & 70 & 904 & $.005^{\star \star}$ \\
\hline \multicolumn{6}{|l|}{$\begin{array}{l}\text {...HIV-positive employees should } \\
\text { not be sacked }\end{array}$} \\
\hline Round 1 & 73 & 7,217 & 77 & 985 & $.017^{*}$ \\
\hline Round 2 & 75 & 6,390 & 72 & 904 & $.032^{*}$ \\
\hline \multicolumn{6}{|l|}{$\begin{array}{l}\text {...employees should not be } \\
\text { forced to have a blood test }\end{array}$} \\
\hline Round 1 & 24 & 7,199 & 32 & 977 & $<.001^{*}$ \\
\hline Round 2 & 29 & 6,377 & 27 & 900 & .113 \\
\hline \multicolumn{6}{|c|}{$\begin{array}{l}\text {...companies should support employees } \\
\text { to have voluntary blood tests }\end{array}$} \\
\hline Round 1 & 74 & 7,192 & 73 & 982 & .691 \\
\hline Round 2 & 74 & 6,367 & 72 & 901 & .447 \\
\hline \multicolumn{6}{|l|}{$\begin{array}{l}\text {...HIV-positive employees should } \\
\text { receive the same conditions as } \\
\text { other workers }\end{array}$} \\
\hline Round 1 & 81 & 7,201 & 81 & 984 & .978 \\
\hline Round 2 & 82 & 6,383 & 81 & 900 & .863 \\
\hline
\end{tabular}




\section{Hgrizons}

Figure 8 Employee attitudes toward PLHA

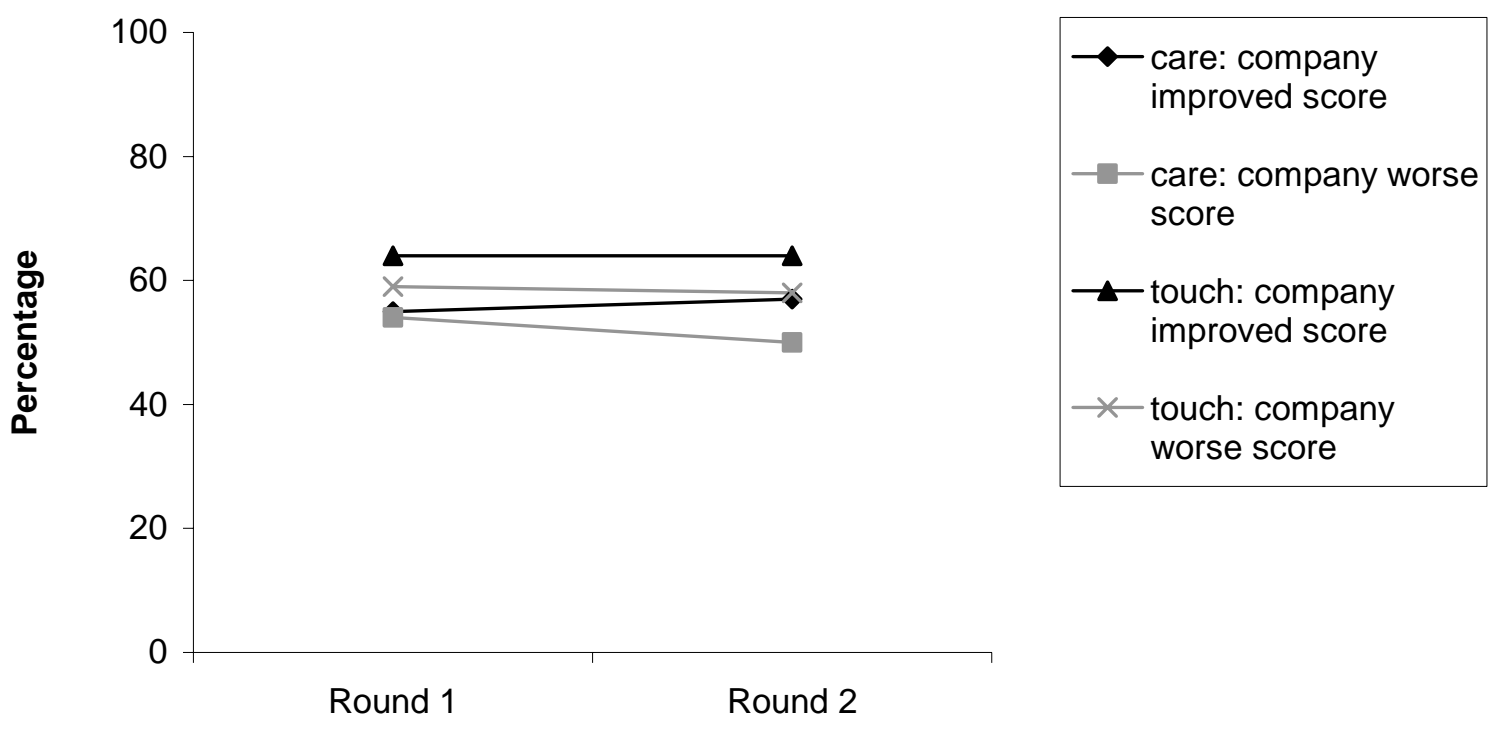

\section{Behavior}

Researchers found little evidence of behavior change reported by employees over the course of the study, and few differences in employees' behavior between companies whose scores improved and deteriorated (Table 20). The only statistically significant reported change was in the percentage of employees having conversations about HIV/AIDS in the last year, but this too was of very minor actual impact. 
Table 20 Employees' reported risk behavior, by companies' accreditation score change

\begin{tabular}{|c|c|c|c|c|c|}
\hline & \multicolumn{2}{|c|}{$\begin{array}{l}\text { Companies with } \\
\text { improved score }\end{array}$} & \multicolumn{2}{|c|}{$\begin{array}{l}\text { Companies with } \\
\text { worse score }\end{array}$} & \multirow{2}{*}{$\begin{array}{l}\text { Significance } \\
\text { (Pearson } \\
\left.\text { chi }^{2}\right)\end{array}$} \\
\hline & $\%$ & n & $\%$ & $\mathbf{n}$ & \\
\hline \multicolumn{6}{|c|}{$\begin{array}{l}\text { Male employees who had sex with } \\
\text { a sex worker (SW) in the last year }\end{array}$} \\
\hline Round 1 & 25 & 3,109 & 27 & 539 & .322 \\
\hline Round 2 & 24 & 2,713 & 28 & 483 & .079 \\
\hline \multicolumn{6}{|c|}{$\begin{array}{l}\text { Male employees who always used } \\
\text { a condom when visiting a SW in } \\
\text { the last year }\end{array}$} \\
\hline Round 1 & 72 & 740 & 74 & 141 & .605 \\
\hline Round 2 & 76 & 633 & 73 & 132 & .476 \\
\hline \multicolumn{6}{|c|}{$\begin{array}{l}\text { Employees who had sex with some- } \\
\text { one who was not his/her husband/ } \\
\text { wife nor a SW in the last year }\end{array}$} \\
\hline Round 1 & 31 & 5,508 & 31 & 801 & .579 \\
\hline Round 2 & 40 & 4,973 & 43 & 713 & .051 \\
\hline \multicolumn{6}{|c|}{$\begin{array}{l}\text { Employees who always used a } \\
\text { condom when having sex with a } \\
\text { person who was not their } \\
\text { husband/wife or SW }\end{array}$} \\
\hline Round 1 & 42 & 775 & 43 & 111 & .774 \\
\hline Round 2 & 28 & 1,905 & 28 & 300 & .805 \\
\hline \multicolumn{6}{|c|}{$\begin{array}{l}\text { Employees who had conversations } \\
\text { with friends about HIV/AIDS in the } \\
\text { last year }\end{array}$} \\
\hline Round 1 & 82 & 7,319 & 81 & 994 & .376 \\
\hline Round 2 & 83 & 6,506 & 79 & 928 & $.007^{* *}$ \\
\hline
\end{tabular}




\section{Cost-benefit Analysis}

Precise estimation of the costs and benefits of participation in ASO is an extremely difficult task, requiring calibration of nonmonetary costs. The approximation that follows below is based on data collected from company managers in both survey rounds.

\section{Companies}

The costs associated with company participation in ASO were determined based on estimates of the direct and indirect costs of:

- Managers' responsibilities in making the decision to join ASO, developing company HIV/AIDS policies, and being interviewed for the company surveys.

- Employees who completed the SAQ, attended HIV/AIDS training sessions, received HIV/AIDS information, and/or received counseling during working hours.

- Specially designated staff responsible for organizing HIV/AIDS training, disseminating information, distributing and/or selling condoms, counseling, and visiting PLHA..

Table 21 below suggests that AIA client companies appeared to spend more money on changing their HIV/AIDS programs and policies than non-AIA clients. The high variability of these estimates may be due to the fact that a small number of companies carried out HIV/AIDS training for most of their workforces, incurring disproportionately high costs. Furthermore, few companies were able to provide researchers with cost information to this degree of detail.

Table 21 Estimated cost and benefits of the ASO project

\begin{tabular}{|c|c|c|c|c|c|c|c|c|}
\hline & \multicolumn{4}{|c|}{ Costs per company } & \multicolumn{4}{|c|}{ Costs per employee } \\
\hline & \multicolumn{2}{|c|}{ Mean } & \multicolumn{2}{|c|}{ Median } & \multicolumn{2}{|c|}{ Mean } & \multicolumn{2}{|c|}{ Median } \\
\hline & $\begin{array}{c}\text { Round } 1 \\
n=83\end{array}$ & $\begin{array}{c}\text { Round } 2 \\
n=86\end{array}$ & $\begin{array}{c}\text { Round } 1 \\
n=83\end{array}$ & $\begin{array}{c}\text { Round } 2 \\
n=86\end{array}$ & $\begin{array}{c}\text { Round } 1 \\
n=83\end{array}$ & $\begin{array}{c}\text { Round } 2 \\
n=86\end{array}$ & $\begin{array}{c}\text { Round } 1 \\
n=83\end{array}$ & $\begin{array}{c}\text { Round } 2 \\
n=86\end{array}$ \\
\hline \multirow{2}{*}{$\begin{array}{l}\text { Non-AIA } \\
\text { clients }\end{array}$} & 13,907 & 18,600 & 3,104 & 3,700 & 22 & 33 & 10.3 & 9.3 \\
\hline & $\begin{array}{c}\text { Round } 1 \\
n=42\end{array}$ & $\begin{array}{c}\text { Round } 2 \\
n=31\end{array}$ & $\begin{array}{c}\text { Round } 1 \\
n=42\end{array}$ & $\begin{array}{c}\text { Round } 2 \\
n=31\end{array}$ & $\begin{array}{c}\text { Round } 1 \\
n=42\end{array}$ & $\begin{array}{c}\text { Round } 2 \\
n=31\end{array}$ & $\begin{array}{c}\text { Round } 1 \\
n=42\end{array}$ & $\begin{array}{c}\text { Round } 2 \\
n=31\end{array}$ \\
\hline $\begin{array}{l}\text { AlA } \\
\text { clients }\end{array}$ & 43,870 & 274,686 & 10,000 & 13,500 & 141 & 569 & 20.7 & 31.9 \\
\hline
\end{tabular}

Note: All costs are in baht; 42 baht is equivalent to $\$ 1$.

This study is unable to capture the comparative costs of taking no measures against HIV/AIDS, including the nonmonetary costs associated with declining morale and the monetary costs 
associated with absenteeism, lost productivity, and increased staff turnover (hiring and training). These costs will increase as HIV prevalence increases and more employees are affected and infected by HIV/AIDS. Furthermore, the nonmonetary benefits of improved staff morale and company public image from participation in ASO have not been included in the analysis.

To be honest, what I think is the case is that those companies that joined the project are concerned about their public image. It shows that they care for their employees.

Manager, large nonparticipating company

\section{Insurance provider}

AIA, the life insurance policy provider, estimated that it spent 3,251,874 baht on the ASO project, including expenditures on personnel and operations administration costs, funding a public relations program, producing printed materials, and covering reductions on the group life insurance rates.

AIA gained limited short-term and/or financial benefits from participation in the ASO project. ASO was not used as a marketing promotion to recruit new clients for group life insurance. However, in the long term, AIA gained the benefit of national and international recognition for its involvement in an effective HIV/AIDS prevention and nondiscrimination program, funded through its own Community Fund. Public recognition for AIA to date has included commendations from the Thai Ministries of Public Health and Labour and Social Welfare, high-profile presentations at national and international conferences, and the inclusion of the ASO project on the international "best practice" list of the Global Business Council on AIDS. The World Economic Forum has also shown interest in the project.

In the long term, another possible benefit for AIA would be the achievement of a reduction in HIV/AIDS in Thailand, which was stated as one of the project's main goals. Apart from the wider societal value of this worthy goal, reducing HIV/AIDS in Thailand would enable AIA to gain the additional benefit of reduced medical and life insurance claims by policyholders. Even if the project is successful, such a benefit would not be seen for many years, given the time from the onset of the disease to emergence of health problems. 


\title{
Hgrizons
}

\section{Lessons Learned}

\begin{abstract}
Managers were more motivated to get involved in the initiative by a feeling of social responsibility to improve their policies and programs than by the program incentives.
\end{abstract}

The study revealed the encouraging finding that the most popular reason for joining the program cited by managers was an altruistic sense of responsibility to act in the best interests of their employees. Nearly 60 percent of the 125 participating company managers choosing to join ASO reported that they decided to participate out of a sense of responsibility to their workers and the wider community to do something about HIV/AIDS. Managers indicated that they felt that joining the program was "the right thing to do," both for their employees and for the community in which they live and work. The ASO program provided a timely and effective vehicle for the expression of this belief. Other motivations reported by managers to join the initiative were that ASO would allow them to find out how their HIV/AIDS policies and programs compare to those of other companies and to better understand the disease and how employees may be at risk due to their behavior.

The financial and public recognition incentives were not found to be popular motivating factors for participation in the scheme. Few managers reported that they were motivated to join ASO because of the possibility of achieving a cost reduction in their group life insurance premiums. Only 11 percent of managers who participated said that they had joined ASO for its financial benefits, while the rest-particularly smaller companies with fewer resources-did not perceive the premium reduction as being sufficient to justify the additional costs of introducing the policies and activities. With life insurance coverage costing employers an average premium of 250 baht (US \$5.85) per employee, the maximum reduction available was 25 baht (US \$0.59) per employee.

The certificate introduced during the project also did not provide sufficient motivation to encourage company managers to join the ASO scheme. In spite of the high-profile award ceremony, some company managers felt that the program was not widely recognized. Researchers discovered that an additional incentive to recruitment would be the achievement of high-level patronage, from international organizations (e.g., ILO, UNAIDS) or the Thai royal family, in order to distinguish the ASO certificate from other competing certificates. Another possible strategy would be to increase public and professional awareness of the project and advocate for company participation, so that achievement of the certificate would become a more widely recognized goal.

\section{Managers with close or preexisting connections to the initiative (physical location, staff contacts, company commitment to HIV) were more likely to participate.}

Overall participation in the initiative was 15 percent of the 857 companies originally invited. Participating companies included factories, hotels, and commercial and professional firms, and companies of diverse size and ownership characteristics. Company characteristics associated with higher levels of participation in the initiative included a history of previous involvement in 
HIV/AIDS activities and the manager's personal commitment to the issue. The most successful contact method of recruiting companies was approaching personal contacts. Locally owned and headquartered companies had significantly higher participation levels than those in which the locus of decision making was physically more distant. Companies with higher numbers of employees insured by AIA, to whom the fixed costs of the required policy changes represented a proportionately smaller burden, were more likely to sign up to the initiative.

\section{Most participating companies improved their HIV/AIDS policies and programs.}

Among those companies that participated in the initiative, researchers found marked improvements in HIV/AIDS policies and programs that indicated the creation of a more favorable workplace environment. Between the two survey rounds, the mean total accreditation score to evaluate HIV/AIDS policies and programs increased from 37 to 51 points out of a maximum of 100 (p < $.001)$. Accreditation scores improved at 82 percent of participating companies.

\section{Among participating companies, financial incentives were associated with greater policy improvements.}

The evidence above suggested that financial incentives alone provided insufficient motivation for company recruitment to the initiative. However, once recruited, those companies eligible for the financial incentive showed greater improvements in their HIV/AIDS activities than other companies that did not stand to gain any financial reward from policy implementation.

About a third of 125 companies that joined ASO (34 percent) held AIA group life insurance policies and were eligible for premium reductions. These AIA member companies showed greater improvements in their policies and spent more to improve their programs than did non-AIA member companies that joined ASO and were ineligible for financial benefits.

Although the financial incentive was perceived to be insufficient to motivate many companies to join ASO, it likely played a positive role once companies had already signed up. AIA member companies showed greater improvements in their policies and spent more to improve their programs than did the non-AIA member companies that joined ASO and were thus ineligible for financial benefits. Financial rewards can clearly have an impact on company polices and programs, but their influence in this study was limited to policy implementation and not company recruitment. Further research is needed to determine the threshold level of financial incentive which, combined with efforts to tap into managers' willingness to respond to the epidemic, will be a sufficient motivator to effect improvements in workplace environments. The question remains as to whether it is either realistic or socially desirable to expect insurance companies to provide larger incentives to their members and assume the burden of corporate social responsibility. 


\section{Hgrizons}

\section{Broad policy improvements were not associated with changes at the employee level.}

The self-administered employee surveys indicated very limited impact of workplace improvements on the knowledge and behavior of individuals, even those employed by companies whose workplace policies improved. This is not surprising, since the basic policy changes required by ASO were subtle and unlikely to effect major or immediate change directly on employees. The focus of ASO was on nondiscriminatory policies, which help to safeguard workers' rights but likely do little to directly foster sexual risk-reduction behaviors. The long-term changes at which these policy improvements were aimed cannot be captured by short-term employee surveys.

Furthermore, while TBCA offered companies a menu of materials and services to improve workplace HIV/AIDS programs, the inputs requested may not have been sufficiently intense to result in improvements robust enough to make a difference in workers' knowledge and behaviors. Therefore, in future endeavors, more attention needs to be paid not only to participation but to the program content of HIV/AIDS workplace activities.

\section{The recruitment process and data collection methods can be improved by streamlining.}

The study revealed additional unforeseen weaknesses in the recruitment process. Future scale-up must recognize the finding that some company managers incorrectly perceived the ASO scheme to be an AIA marketing policy. The nonpartisan nature of the scheme must be clarified from the outset, perhaps by endorsement from the Thai Insurance Association (an umbrella organization representing all insurance companies in Thailand) or a wider collective of private industry or government agencies. Sponsorship from a government agency or industry-wide body would also have greater potential for investment in public relations materials and reaching more companies than was possible by an NGO with limited financial resources.

As the program is scaled up, continuing research should determine whether an NGO with expertise in HIV/AIDS, a private enterprise, or a government department would be more successful in recruiting private enterprises to undertake HIV/AIDS workplace activities. Would direct involvement from government departments, which could force private enterprises to undertake such activities, result in companies introducing token or substantive HIV/AIDS programs?

Recruitment procedures need to be better planned and executed, to avoid discouraging managers who declined to join because the sign-up process appeared overly complicated. Company databases must be checked and updated before any contact is made to ensure that senior management and human resource directors are correctly and directly approached. Clear policy directions regarding the language (Thai, English or both), timeframe (sufficient time before planned project implementation), and mode of contact (fax, telephone, face-to-face) are required.

The study invested significant resources in collecting data from employees and company managers, because it was unclear how reliable managers' responses alone would be when they stood to gain a financial incentive by claiming that they had introduced new HIV/AIDS policies and programs. Administering the SAQ to large numbers of employees was time-consuming, administratively 
complicated, and expensive in terms of the opportunity cost of alternate activities for employees and employers. Further analysis is required to determine the degree of consistency between manager and employee responses and the extent to which the resource-intensive employee data could be replaced by data collected from managers. Relying on information about company programs and policies collected from managers alone could substantially reduce the costs of data collection, and simplify the complicated logistics that previously served as a disincentive to company participation. 


\section{Hgrizons}

\section{Next Steps}

Building on the findings of this study, a modified version of the initiative will be scaled up to 25 provinces in Thailand, beginning in late 2003. TBCA has received funding from the Global Fund to recruit 2,500 workplaces to participate in the new program, in cooperation with the Ministry of Public Health, the Ministry of Labour and Social Welfare, business groups, AIA, and local nongovernmental organizations.

Each participating workplace will have to implement four key policies, including the three key policies from the original initiative and the additional policy of explicitly providing HIV/AIDS education to their staff. Managers of participating workplaces will be trained in how to deal with HIV/AIDS in the workplace, and staff members will be trained to be HIV/AIDS trainers for their workplace. The increasing emphasis on these activities will necessitate additional attention to monitoring and quality control and new, longer-term criteria to evaluate their impact.

TBCA has sought and gained further official backing from the Thai Government. The fact that the program will be accredited and endorsed by the Ministry of Public Health and the Ministry of Labour and Social Welfare will be publicized heavily, to improve its public image and enhance its importance and prestige. Invitation letters will be sent on official paper, and managers will become aware early in the recruitment process that senior representatives of the Ministry of Public Health and the Ministry of Labour and Social Welfare will sign the certificates of achievement.

AIA will continue to support the scheme through life insurance premiums, but member reductions will only be available at two discrete levels ( 5 percent and 10 percent), rather than the graduated levels as previously, to reduce administrative requirements. One major change to the scheme will be a new focus on the specific support needs of small and medium-sized enterprises, including very small, informal workplaces.

TBCA has also been working with the International Labour Organisation and the Department of Labour Protection and Welfare in Rayong province to further develop ASO for wider applications and ensure its compliance with internationally recognized guidelines, such as the ILO Code of Practice on HIV/AIDS and the World of Work (e.g., revision of the scores for each element of an HIV/AIDS workplace policy). 


\section{References}

Durban Chamber of Commerce. Undated. "Guidelines for affiliated companies: HIV/AIDS policy and procedure for dealing with life-threatening diseases."

http://www.ilo.org/public/english/protection/trav/aids/examples/durban.pdf. Accessed October 2003.

GIPA. Undated. "The greater involvement of people with AIDS."

http://www.ilo.org/public/english/protection/trav/aids/examples/gipa.pdf. Accessed 2003.

International Labour Organization. 2003a. "Action against AIDS in the workplace: The AsiaPacific Region.” http://www.ilo.org/public/english/protection/trav/aids/publ/menuasiaov.pdf. Accessed October 2003.

_. 2003b. "Examples of workplace action: Cote d'Ivoire Electricity."

http://www.ilo.org/public/english/protection/trav/aids/examples/cotedivoire.htm. Accessed October 2003.

_. 2003c. "Examples of workplace action: Larsen and Toubro Limited, India." http://www.ilo.org/public/english/protection/trav/aids/examples/india.htm. Accessed October 2003.

2003d. "Examples of workplace action: Volkswagen do Brazil."

http://www.ilo.org/public/english/protection/trav/aids/examples/brazil.htm. Accessed October 2003.

Southern African Clothing and Textile Workers' Union. 2002. "Policy and action programme to help combat HIV/AIDS."

http://www.ilo.org/public/english/protection/trav/aids/examples/clothing.pdf. Accessed October 2003.

UNAIDS. 1998. "HIV/AIDS and the workplace: Forging innovative business responses." http://www.unaids.org/publications/documents/sectors/workplace/workptue.pdf. Accessed October 2003.

. 2002. "Action against AIDS in the workplace."

http://www.weforum.org/pdf/Initiatives/GHI_Workplace_Ref_Menu2.pdf. Accessed October 2003.

World Bank. 2000. Thailand's response to AIDS: Building on success, confronting the future. World Bank: Bangkok.

World Economic Forum. Undated a. "GHI case studies and supporting documents." http://www.weforum.org/site/homepublic.nsf/Content/Global+Health+Initiative\%5CGHI+Business +Tools\%5CGHI+Case+Studies+and+Supporting+Documents. Accessed October 2003. 


\section{Hgrizons}

Undated b. "Global health initiative: Private sector intervention case example."

http://www.weforum.org/pdf/Initiatives/GHI_HIV_CaseStudy_AngloGold.pdf. Accessed October 2003.

\section{Further Reading}

Bloom, D. et al. 2001. "HIV/AIDS and the private sector: A literature review, American Foundation for AIDS Research."

http://www.globaltreatmentaccess.org/content/tools/mnc/Bloomreview.pdf. Accessed September 2003.

Centers for Disease Control and Prevention. Undated. "The financial impact of a workplace HIV/AIDS program." http://www.brta-lrta.org/tools/pdf_laborkit/financial.pdf. Accessed September 2003.

. Undated. "A guide to AIDS in the workplace resources." http://www.brtalrta.org/tools/pdf_mngrkit/res_all.pdf. Accessed September 2003.

Family Health International. 2003. "Workplace interventions."

http://www.fhi.org/en/Topics/Workplace+Interventions+topic+page.htm. Accessed October 2003.

International Finance Cooperation. 2000. "Good practice note: HIV/AIDS in the workplace." http://www2.ifc.org/enviro/HIVAIDS_web.pdf. Accessed September 2003.

International Labour Organization. 2001. "The ILO code of practice on HIV/AIDS." http://www.ilo.org/public/english/protection/trav/aids/code/languages/hiv_a4_e.pdf. Accessed September 2003.

Lisk, F. 2002. "Labour market and employment implications of HIV/AIDS ILO, International Labour Organization: Programme on HIV/AIDS and the World of Work."

http://www.ilo.org/public/english/protection/trav/aids/publ/wp1_labourmarket.pdf. Accessed October 2003.

Mistry, N. and B. Plumley. 2002. "HIV/AIDS workplace protocols and practices for businesses in resource poor settings, Global Business Coalition on AIDS."

http://www.businessfightsaids.org/pdf/wpp.pdf. Accessed September 2003. 


\section{Hgrizons $\Lambda$}

Horizons is a global operations research program designed to:

- Identify and test potential strategies to improve HIV/AIDS prevention, care, and support programs and service delivery.

- Disseminate best practices and utilize findings with a view toward scaling up successful interventions.

\section{(2) Population Council}

Horizons is implemented by the Population Council in collaboration with

- International Center for Research on Women (ICRW)

- International HIV/AIDS Alliance

- Program for Appropriate Technology in Health (PATH)

- Tulane University

- Family Health International (FHI)

- Johns Hopkins University

For more information, please contact:

Horizons Program, Communications Unit 4301 Connecticut Avenue, NW Suite 280 Washington, DC 20008 USA

Tel: 202-237-9400

Fax: 202-237-8410

Email: horizons@pcdc.org www.popcouncil.org/horizons 